\title{
Export Diversification and Financial Openness
}

\author{
Sèna Kimm GNANGNON ${ }^{1}$
}

\begin{abstract}
This paper investigates empirically the effect of export diversification (i.e., both export product diversification and services export diversification) on financial openness, using a sample of 119 countries (including both developed and developing countries) over the period 1985-2014. Based on the Blundell and Bond's two-step system Generalized Methods of Moments, the analysis has revealed that both export product diversification and services export diversification influence positively financial openness. However, this outcome hides differentiated effects across countries in the full sample. Specially, countries with a very high real per capita income experience a positive effect of export concentration on financial openness, while for countries with a relatively lower per capita income, it is rather export diversification that drives positively financial openness. Interestingly, the effect of export diversification on financial openness depends on the size of external shocks that affect domestic economies, as well as countries' economic growth performance. Overall, these findings add to the empirical literature on the effect of international trade on financial openness by showing that both export product diversification and services export diversification matter for financial openness.
\end{abstract}

Keywords: Export product diversification; Services export diversification; Financial Openness; Developed and Developing countries.

JEL Classification: F02; F21; F14; F4.

\section{DISCLAIMER}

This is a working paper, which represents the personal opinions of individual staff members and is not meant to represent the position or opinions of the WTO or its Members, nor the official position of any staff members. Any errors or omissions are the fault of the author. The author declares no competing interests.

\footnotetext{
${ }^{1}$ World Trade Organization (WTO). E-mail for correspondence: kgnangnon@yahoo.fr
} 


\section{Introduction}

Opening-up capital account entails many benefits. These include the access to a bigger investor base (e.g., Reese and Weisbach, 2002), to a wide variety of financial instruments (and hence to the possibility of better diversifying risk) (e.g., Obstfeld, 1994), and access to more liquidity. Access to international financial markets also allows firms to obtain funding at lower capital costs, and at longer maturities compared to funding from domestic markets (e.g., Ball et al., 2018; Chouinard and D'Souza, 2004; Schmukler and Vesperoni, 2006; Stulz, 1999; Turk Ariss, 2016). It improves corporate governance and enhances investments (e.g., Benos and Weisbach, 2004), firms' visibility and prestige (e.g., Baker et al., 2002; Bancel and Mittoo, 2001; Herrmann et al. 2015), macroeconomic policies discipline (e.g., Agénor, 2003; Prasad and Rajan, 2008; Tytell and Wei, 2004), and ultimately increases economic efficiency (e.g., Bekaert et al. 2005). However, financial distortions in the context of financial openness may cancel out those benefits (e.g., Eichengreen and Leblang, 2003), and greater financial openness can amplify such distortions, and result in higher economic instability (e.g., Agénor, 2003; Summers, 2000; Wei, 2018). According for example to Claessens and Huizinga (2001), the liberalization of capital account increases competition in the domestic financial sector, which adversely affects local banks in poor countries.

Even though there is no universally agreed definition of financial openness (also referred to as 'capital account openness' or 'financial liberalization'), financial openness can be considered as the process by which countries reduce legal or "de jure" controls that restrict cross-country capital movements. It entails, for example, the elimination of restrictions on capital inflows and outflows, the removal of limits on equity holding by foreigners, and the abandonment of multiple exchange rates or limits to the acquisition of foreign currency (e.g., Arestis et al., 2005; Kose et al., 2010; Schmukler and Facundo, 2017). In that respect, financial openness is different from what is referred in the literature to as 'international financial integration', and considered as the 'de facto' rise in cross-country capital movement (or the potential for those movements to take place).

Many studies ${ }^{2}$ have investigated the macroeconomic determinants of financial openness. International trade appears to play an essential role in financial openness dynamics. Specially, trade openness (or trade policy liberalization) appears to be an important factor underpinning financial openness. Gnangnon (2019) has also recently shown that multilateral trade liberalization matters for financial openness. However, we are not aware of a study that has looked at the effect of export diversification, including both export product diversification and services export diversification, on financial openness. Given that many studies ${ }^{3}$ have demonstrated the importance of export upgrading (both export products and services export upgrading) for economic growth and development prospects in both developed and developing countries, one can question whether export diversification - both export product diversification and services export diversification matters for financial openness.

The current paper aims to fill this gap in the literature. It intends to contribute to the existing literature on the macroeconomic determinants of financial openness by investigating whether

${ }^{2}$ Studies include for example Grilli and Milesi-Ferreti (1995); Gnangnon (2019); Joyce and Noy (2008); Karcher and Steinberg (2013); Obstfeld (1998); Quinn and Inclan (1997); Steinberg et al. (2018); Vo and Daly (2007); and Von Furstenberg (1998).

${ }^{3}$ Studies on this matter include for example, Anand et al. (2012); Gnangnon (2020a; 2020b); Haddad et al. (2013); Hausmann et al. (2007); Kramarz et al. (2020); McIntyre (2018); Mishra et al. (2011); Redding (1999); Stojkoski et al. (2016) and Vannoorenberghe et al. (2016). 
export diversification matters for financial openness. The analysis has been carried out using a sample of 119 countries (both developed and developing countries) over the period 1985-2014. The outcomes show for the full sample that both export product diversification and services export diversification influence positively financial openness, although the direction of this effect appears to be dependent on countries' level of the real per capita income. Additionally, the analysis suggests that export product diversification and services export diversification are substitutable in influencing financial openness when countries are subject to external shocks. Finally, export diversification is associated with greater financial openness in countries that experience a rise in economic growth performance.

The rest of the paper is structured as follows. Section 2 provides a theoretical discussion concerning the effects of export diversification on financial openness. Section 3 lays out the baseline model for carrying out the empirical analysis. Section 4 presents some data analysis, while Section 5 discusses the econometric method for the analysis. Section 6 interprets the empirical outcomes, and Section 7 undertakes a further analysis. Section 8 concludes.

\section{Theoretical discussion on the effects of export diversification on financial openness}

As noted above, capital account liberalization (or financial openness) indicates the extent of the relaxation of official controls on cross-border capital. This section considers two types of export diversification (or concentration/specialization), and discusses how they can affect financial openness. These types of export diversification include export product diversification and services export diversification. In the remainder of the paper, the expression export diversification (unless otherwise clearly specified) means export product diversification and services export diversification.

Olson (1982) and Mathieson and Rojas-Suairez (1993) have emphasized that a country's openness to trade in goods and services also affects its financial liberalization policies. Lane and Milesi-Ferretti (2003) have argued that greater financial transactions (that reflect greater capital account liberalization) are likely associated with corresponding movements in cross-border flows of goods and services. The authors have additionally argued that greater openness of goods market can intensify cross-border financial transactions, and reduce financial home bias (a 'familiarity' effect). Obstfeld and Rogoff (2000) have underlined that trade costs create wedge between marginal rates of substitution and hence, limit the gains to asset trade. This, therefore, underlines the strong connection between the extent of goods trade and the gains arising from financial diversification. Helleiner (1993) has shown that governments use trade openness and financial openness tools to offset political shocks in each other. Quinn and Inclan (1997) have deduced that corporatist nations might be less financially open than other nations. According to Kose et al. (2010), economic policies that help developing countries to reap the benefits of financial globalization are those that contribute to the enhancement of the development of the financial sector, the promotion of trade openness and the improvement of institutional quality. These findings show that greater openness is likely to be associated with greater financial openness.

Nevertheless, Bekaert and Harvey $(1997,2000)$ have tempered this view by arguing that trade openness can induce a greater exposure of the local market to global risk factors. As a result, policymakers might be willing to modulate the degree of financial openness so as to reduce such 
local market's exposure. While these clearly show that grater trade openness can induce a higher of financial openness, these findings, at least, show that higher cross-border movements of goods and services likely reflect corresponding greater financial transactions. At the same time, these cross-border goods and services flows reflect for a given country, either export product concentration (or diversification), and services export concentration (or diversification). This signifies that either export product diversification or export product concentration can be associated with higher financial openness. Likewise, services export concentration or services export diversification can be associated with greater capital account liberalization. At this stage of the analysis, it is difficult to anticipate whether it is export diversification (i.e., export product diversification and services export diversification) or export concentration (i.e., export product concentration and services export concentration) that positively influences financial openness.

\section{Export product specialization and services export specialization can be positively associated with financial openness}

Eckel (2008) has shown theoretically that increased specialization is desirable because it enhances countries' efficiency and competitiveness, and can consequently has significant welfare implications. Specially, the author has shown that globalization (that entails both trade and financial openness) can adversely affect per capita output and reduce welfare if specialization falls, and losses from it are larger than gains arising from increases in firm size (due to globalization).

On the other hand, the opening-up of capital account can allow firms to have access to a wide variety of financial instruments, which provides opportunities for better risk diversification (e.g., Acemoglu and Zilibotti, 1997; Greenwood and Jovanovic, 1990; Obstfeld, 1994; Saint-Paul, 1992). It also provides for access to more liquidity; to funding at lower capital costs, and at longer maturities compared to funding from domestic markets (e.g., Ball et al., 2018; Chouinard and D’Souza, 2004; Schmukler and Vesperoni, 2006; Stulz, 1999; Turk Ariss, 2016). The risk-sharing opportunities (i.e., the greater protection against idiosyncratic risks) provided by greater financial openness can allow countries to enhance production specialization (through production differentiation) in order to fully exploit economies of scale or technological competitive advantages. The rationale for this is that open and integrated financial markets allows for access to a wide range of financial instruments, while also favouring the diversification of ownership through two types of insurance, including an ex ante international insurance, and an ex post adjustment of asset portfolios (e.g., Bos et al., 2020). As for the first type of insurance, it is argued that by holding debt and equity claims on the output of another country (and hence the dividend, interest and rental income derived from these holdings), residents in one country can smooth the effects of output shocks across countries. The insurance mechanism that involves the ex post adjustment of asset portfolios provides that households in each country can ex post adjust their asset portfolios so as to smooth out consumption further in the wake of shocks in the region. This would, therefore, lead to an income smoothing across all countries. Along the same lines, Imbs (2004: page 1) has pointed out that the risk-sharing induced specialization arising from financial openness can be explained by the fact that greater financial openness offers access to an increasing range of state-contingent securities, which unhinges domestic consumption patterns from domestic production, and hence provides countries with the opportunity to specialize according to comparative advantage (see also Grossman and Razin, 1985; Helpman and Razin, 1978; Imbs, 
2006; Kalemli-Ozcan et al., 2003; Saint-Paul, 1992). For example, ${ }^{4}$ Kalemli-Ozcan et al. (2003) have found that risk sharing from financial openness is positively associated with production specialization across some OECD countries, as well as among regions in the USA. These findings have been confirmed by Basile and Girardi (2010) for European regions. Artis and Hoffmann (2007) and Sorensen et al. (2007) have reported that the level of financial openness increases as risk sharing improved among industrialized countries. Bos et al. (2020) have found empirically that greater financial openness (to a higher extent than trade openness) has been positively associated with production specialization. Additionally, they have obtained that this positive production specialization effect of financial openness holds only when countries enjoy greater trade openness. However, authors such as Moser et al. (2004) and Bai and Zhang (2006) have obtained little support for these findings, as their studies have revealed that there was really no improved risk sharing despite massive financial openness.

Against this background, one can expect greater production specialization to be associated with greater financial openness. According to De Benedictis et al. (2003), production and export forces are different but interlinked phenomena. Therefore, by extension, we can also infer that export product specialization (concentration) can be associated with greater financial openness. At the same time, while there might be some differences between goods and services (e.g., Hill, 1977; Morgan and Snowden, 2007), such differences might not apply to trade (e.g., Hindley and Smith, 1984). In this context, authors such as Kimura and Lee (2006); Nyahoho (2010) and van der Marel (2012) have shown that the international trade theory that applies to trade in goods could also apply to trade in services. In light of the postulated positive effect of export product specialization on financial openness, we also argue here (by extension) that services export specialization can induce greater financial openness. Overall, we can argue that export specialization (be it in goods or in services) could be positively associated with capital account liberalization (Hypothesis 1).

Meanwhile, it is also possible that export diversification (for both products and services) influences positively financial openness, depending on how it affects countries vulnerability to shocks, and their economic growth performance. We discuss below how these two channels could operate.

\section{Export product diversification and services export diversification can induce greater financial openness}

There is a shared view among researchers, scholars and policymakers at both the national and international levels that countries should specialize in high-valued added export products ${ }^{5}$ to ensure a sustainable economic growth and development path. In particular, developing countries should diversify their export product baskets away from primary commodities (e.g., Hausman et al. 2007; Herzer and Nowak-Lehmann, 2006; Naudé et al. 2010, 2011; Redding, 1999; Prebisch, 1950; Singer, 1950). Export product diversification (including towards manufactured products) has many positive macroeconomic effects, of which, reducing countries' vulnerability to external shocks, dampening terms of trade instability and promoting economic growth. Export product diversification can help mitigate countries' vulnerability to external shocks ${ }^{6}$, notably by dampening

\footnotetext{
${ }^{4}$ Kose et al. (2009) have provided a literature survey on the matter.

${ }_{5}$ For example, Hausmann et al. (2007) have shown that as far as the relationship between export product structure and economic growth is concerned, what matters is the type of countries' exports, including the sophisticated nature of those exports.

${ }^{6}$ Countries are often confronted with external shocks such as commodity prices shocks, export demand fluctuations, sudden surges or reversals of capital flows, natural disasters, diseases,..etc. More than developed countries, developing ones
} 
the effect of these shocks on domestic economies, through for example, reducing aggregate output volatility ${ }^{7}$ as well as mitigating firms' output volatility (e.g., Kramarz et al. 2020; Vannoorenberghe et al. 2016). Export product diversification also helps reduce terms of trade instability, and hence export revenue instability ${ }^{8}$ (e.g., Asheghian and Saidi, 2002; Athukorola, 2000; Love, 1986, 1987; Prebisch, 1950; Singer, 1950; Stanley and Bunnag, 2001).

On the other hand, services export diversification also plays an important role in reducing countries' exposure to external shocks. In fact, few, but interesting studies have provided empirical evidence that services trade, in particular services exports exhibit a strong resilience to shocks and financial crises, and even more so than goods exports (e.g., Ariu, 2016; Borchert and Mattoo, 2010). Using trade data on United States and some other OECD countries, Borchert and Mattoo (2010) have noted that during the global financial crisis, services trade has resisted much better than goods trade. They have also observed that developing countries such as India that are relatively specialized in modern services, including business process outsourcing and information technology services, have experienced a much smaller fall in total exports to the United States than the Africa region, as well as countries such as Brazil and China, which are specialized in exports of goods, transport services, or tourism services. Then, the authors have moved on to examine data on India exporters in the Information Technology sector, and put forth two reasons to explain the higher resilience of trade in services than trade in goods to shocks and financial crises. First, trade in services displays a lesser cyclical nature compared to trade in goods. Second, services production and trade are less dependent on external finance compared to goods production and trade. Arin (2016) has documented that modern business services have shown a higher resilience than traditional services to shocks. Using trade data at the firm-product-destination level for Belgium, the author has found empirical evidence that during the 2008-2009 global financial crisis, the elasticity of services exports with respect to GDP growth in trading partners was significantly different from that of goods exports. Specifically, the negative income shock in partner countries has resulted in lower goods exports, but has not affected services exports. Overall, these signify that services exports, and eventually services export diversification can play a key role in mitigating output (or economic growth) volatility.

On another note, we also argue that the effect of export product diversification (or concentration) and services export diversification (or concentration) on financial openness can translate through the economic growth performance channel. This is because, it is now widely acknowledged that economic performance, including economic growth is an important factor (among pull factors) that drives capital flows in countries (e.g., Agénor, 2003; Ahmed and Zlate 2014; Calvo et al., 1993; Fernandez-Arias, 1996; Fernandez-Arias and Montiel, 1996; Fratzscher, 2012; Ghosh et. al., 2014; Guichard, 2017; Hannan 2017; Qureshi and Sugawara, 2018; Vo and Daly, 2007). As for the relationship between export product diversification and economic growth, the empirical evidence is mixed. Some studies have reported a positive effect of export product diversification (including towards sophisticated products) on economic growth (e.g., Can and

experience a high persistence of shocks (e.g., Aguiar and Gopinath, 2007), and a higher frequency of such shocks (e.g., Álvarez et al., 2018; Barrot et al. 2018; Cariolle et al. 2016; Dabla-Norris and Gündüz, 2014; Essers, 2013; Guillaumont, 2009, 2017; IMF, 2008, 2013).

${ }^{7}$ See for example Bacchetta et al. (2007); Balavac and Pugh (2016); Camanho da Costa Neto and Romeu (2011); di Giovanni et al. (2014); Haddad et al. (2013); Joya (2015); Koren and Tenreyro (2007); Malik and Temple (2009); McIntyre (2018); and Strobl (2005).

${ }^{8}$ Macbean and Nguyen (1980) have, nevertheless, provided a theoretical framework, which shows that in practice, commodity concentration might not be the main explanation of export earnings instability in developing countries. 
Gozgor, 2017; De Pineres and Ferrantino, 1997; Hausman et al. 2007; Herzer and NowakLehmann, 2006; Naudé et al. 2010). Aditya and Acharyya (2013) and Hess (2008) have uncovered the existence of a non-linear relationship between export product diversification and the real per capita income growth. Specially, export product diversification spurs economic growth in developing countries, while export specialization enhances economic growth in most advanced countries. Mania and Rieber (2019) have obtained heterogenous outcomes when examining the effect of export product diversification on sustainable economic growth in developing countries, including across Latin America, Sub-Saharan Africa and Developing Asia. Naudé et al. (2011) have examined the relationship between export diversity and economic performance, focusing on Brazil, China, India and South Africa, over the period 1962-2000. They have found that while export product diversification has exerted a positive effect on per capita income in South Africa, it is rather export product specialization that has been positively associated with economic growth in Brazil, China and India. The authors have, therefore concluded that the manner in which export diversification is obtained might play a significant role in explaining its influence on per capita income. In contrast with Naudé et al. (2011), Matthee et al. (2016) have shown for South Africa that exporting goods that are distant from the country's comparative advantage does not result in higher economic growth.

Regarding the relationship between services export diversification and economic growth performance, Gnangnon (2020a, 2020b) have shown that in developing countries, services export diversification promotes economic growth, while in high income countries, it is rather services export specialization that enhances economic growth. In related studies, Anand et al. (2012), Mishra et al. (2011) and Stojkoski et al. (2016) have uncovered empirically that services export sophistication is positively associated with economic growth, and provides countries, including developing ones with a promising avenue for promoting economic growth in the context where the traditional industrialization path contributes less to ignite growth.

Building on the above literature review, we argue that export diversification (i.e., for both products and services) can influence the degree of financial openness through their effect on the external shocks channel, as well as the economic growth performance channel. In fact, the above literature review has shown that both export product diversification and services export diversification can affect financial openness by dampening countries' vulnerability to external shocks and promoting economic growth. Thus, the effect of export diversification (for both products and services) on financial openness through these two main channels would depend on how each of these channels influence the level of financial openness. Financial openness can influence countries' vulnerability to external shocks, including through greater output volatility (e.g., Buch et al., 2005), crises and greater macroeconomic instability (e.g., Aghion et al., 2004; Gluzmann and Guzman, 2017; Lee et al. 2016; Pisani, 2011; Shikimi and Yamada, 2019; Tornell, 2004). In such a case, policymakers would likely modulate the degree of capital account liberalization by adopting capital control measures so as to restrict the volume of capital inflows. Therefore, it is likely that export diversification would be positively associated with financial openness in countries that experience higher vulnerability to external shocks, as it would help mitigate the effect of such shocks on the degree and financial openness, eventually avoid the adoption of strong restrictive measures of capital account openness (Hypothesis 2). 
It is also widely acknowledged that economic performance, including economic growth is an important factor (among pull factors) that drives capital flows in countries ${ }^{9}$. In this context, the effect of export product diversification on financial openness is a priori undetermined and remains an empirical matter, given that it is still unclear whether it is export product diversification or export product specialization that influences positively economic growth. Similarly, it remains unclear whether it is services export diversification or services export specialization that would induce financial openness through the economic growth channel. This is because the effect of services export diversification on economic growth depends on countries' level of development, proxied by the level of their real per capita income. Against this backdrop, the effect of export diversification (goods or services) on financial openness through the economic growth channel is an empirical matter (Hypothesis 3).

\section{Model specification}

We explore empirically the effect of export diversification on financial openness by relying on the existing studies on the macroeconomic determinants of financial openness (e.g., Grilli and Milesi-Ferreti, 1995; Gnangnon, 2019; Joyce and Noy, 2008; Karcher and Steinberg, 2013; Quinn and Inclan, 1997; Steinberg et al., 2018; Vo and Daly, 2007) and considering control variables that would potentially influence the effect of export diversification on financial openness. Thus, control variables introduced in the baseline model are the real per capita income, denoted "GDPC", which is a proxy for countries' development level; the population size, denoted "POP", which represents the country's size, that is, the domestic market size; the inflation rate, denoted "INFL"; the level of trade openness, denoted "OPEN"; the level of human capital accumulated, denoted "HUM"; and the level of democracy, denoted "DEM", which concurrently acts as a proxy for the institutional and governance quality.

The effect of trade openness on financial openness has already been discussed in the previous section, and it is not worth repeating this discussion here. Based on this discussion, we postulate that greater trade openness would influence positively capital account liberalization.

Rich and well-educated countries tend to experience a greater financial integration, and hence enjoy a greater financial openness (e.g., Edison et al. 2002; Joyce and Noy, 2008; Prasad et al. 2003; Steinberg et al., 2018; Vo and Daly, 2007). Olson (1982) has argued that real per capita income may affect capital account liberalization if lower income per capita results in a fall in the demand for capital protection. Therefore, we expect a rise in the real per capita income, as well as an improvement in human capital to be positively associated with financial openness.

Market size (proxied for population size) matters for capital inflows, including for example foreign direct investment (FDI) inflows (e.g., Chakrabarti, 2001; Eaton and Tamura, 1994; Swamy and Narayanamurthy, 2017; Tokunaga and Iwasaki, 2017). In fact, countries with large populations provide multinationals enterprises with a large market for products and services. As a result, policymakers in countries with large populations might need to open-up capital account in order to attract capital inflows, including FDI ones. Likewise, as a growing population makes capital less

9 See for example Agénor (2003); Ahmed and Zlate (2014); Calvo et al. (1993); Fernandez-Arias (1996); Fernandez-Arias and Montiel (1996); Fratzscher (2012); Ghosh et. al. (2014); Guichard (2017); Hannan (2017); Qureshi and Sugawara (2018); and Vo and Daly (2007). 
abundant (e.g., Henry, 2007), policymakers might need to further open-up capital account liberalization so as to attract capital inflows. However, it is also possible that a surge in capital inflows that destabilize countries with large populations could lead policymakers of these countries to adjust consequently the level of capital account liberalization.

Concerning the financial openness effect of inflation, we expect a negative effect of higher inflation rates on financial openness, i.e., inflation would induce a tighten of controls on capital account. This is because as higher capital inflows exert inflationary pressures in recipienteconomies (e.g., Calvo, 1996; Calvo et al., 1993; Montiel, 1996), authorities can tighten controls on these inflows so as limit these capital inflows and reduce the inflationary pressures. Similarly, a rise in the inflation rates would induce greater macroeconomic instability, which would reduce the willingness of foreign investors to invest in the economies. Finally, there is a widespread perception that stable economic conditions (proxied by lower inflation) are essential for attracting capital inflows. Lemmen and Eijffinger (1996) and Steinberg et al. (2018) have reported a negative effect of inflation on capital account liberalization.

Financial development influences positively financial openness (e.g., Henry, 2000a, b; Vo and Daly, 2007; Von Furstenberg, 1998). Levine and Zervos (1996) have argued that the ability to raise funds and diversify risk is positively associated with the market size. Portes and Rey (1999) have documented that the market size, transaction costs and informational frictions influence the level of gross cross-border capital flows. Henry $(2000 \mathrm{a}, \mathrm{b})$ has reported a positive effect of financial development on investment and international financial integration. Well-developed domestic financial markets contribute to attracting foreign investors who can diversify their investment portfolio, which in turn help to promote international financial integration (Vo and Daly, 2007). Thus, one can expect a positive effect of financial development on financial openness. However, according to Vo and Daly (2007), capital controls play an essential role in the context of integrated financial market where monetary policy cannot be used as a policy instrument to control interest rates and exchange rates simultaneously. In such a case, controls on capital inflows and outflows allow to modulate the real exchange rate movements, and therefore induce policymakers to pursue "inconsistent" monetary policies for a while. This argument matters much more for developing economies than for developed ones. In the same vein, Lemmen and Eijffinger (1996) have argued that high (low) degrees of development of domestic financial markets may reflect the increased presence of capital export (import) controls, and this limits international financial integration. As a consequence, financial development can be negatively associated with financial openness.

Steinberg et al. (2018) have elaborated extensively on how democracy can affect decisions concerning capital account policy. For example, if citizen do not support the liberalization of capital account (or are against the controls of capital flows), they would likely vote against the incumbent at the next election. In countries featured by large foreign-currency denominated deposits or loans, citizens would likely oppose the adoption of measures in favour of restricting financial openness. This is because such measures would limit their ability to conduct international financial transactions, and adversely affect their welfare. Furthermore, more than in autocratic countries, organized interest groups can lobby in favour of their preferred capital policies in democracies (e.g., Gallagher, 2015). As a result, officials that aim to be re-elected would wish to avoid public criticism from those interest groups, including by going along with the desire of interest groups. Regardless of the influence of interest groups on policymakers' decisions on capital account policies, elected officials would weigh the advantages and adverse economic consequences 
of capital controls on various economic outcomes, when adopting decisions about capital account policy. Thus, incumbent governments would take into account social interest in any decision pertaining to capital account policy in democratic countries. Overall, as noted by Steinberg et al. (2008: page7), 'democracy contributes to financial openness when diffuse societal groups support this policy or when politicians expect them to benefit from it.' The authors have used country-level data as well as firm-level data to show that the effect of democracy on financial openness at home depends on the level of financial openness abroad. Specially, democracy induces greater financial openness when proximate countries maintain open-capital markets. Overall, it is difficult to anticipate the direction of the effect of democracy on financial openness.

We consider the following baseline model:

FINOPEN $_{i t}=\alpha_{1}$ FINOPEN $_{i t-1}+\alpha_{2}$ EXPC $_{i t}+\alpha_{3} G D P C_{i t}+\alpha_{4}$ OPEN $_{i t}+\alpha_{5} D E M_{i t}+\alpha_{6}$ HUM $_{i t}+$ $\alpha_{7} I N F L_{i t}+\alpha_{8} P O P_{i t}+\mu_{i}+\gamma_{t}+\omega_{i t}$

The estimation of this model specification (as well as several variants of it described later) has been performed over an unbalanced panel dataset of 119 countries (both developed and developing countries), with data spanning the period 1985-2014, based on its availability. i and t represent respectively a country, and the time-period. To mitigate the business cycles effects on variables in model (1), we have followed the practice in the empirical literature by averaging data over nonoverlapping sub-periods of 5-year. These sub-periods are 1985-1989; 1990-1994; 1995-1999; 20002004; 2005-2009; and 2010-2014.

$\mu_{i}$ represent countries' time-invariant fixed effects; $\gamma_{t}$ are time dummies that represent global shocks influencing together all countries' levels of financial openness. $\omega_{i t}$ is a well-behaving error term. We have included the one-period lag of the dependent variable as a regressor in model (1) to account for the fact that financial reforms are likely to display a strong inertia (e.g., Quinn and Inclan, 1997).

The list of variables contained in the baseline model (1), as well as those that are used later in the analysis, are described in Appendix 1.

The dependent variable "FINOPEN" is the index of financial openness (or capital account openness). It is measured by the Chinn-Ito index (Chinn and Ito, 2006), which codifies the tabulation of restrictions on cross-border financial transactions reported in the IMF's Annual Report on Exchange Arrangements and Exchange Restrictions. Initially, its values range between 0 and 1 , but for the purpose of the present study, we have multiplied these values by 100 . So, the index holds values ranging between 0 and 100. Higher values of this index reflect greater financial openness, while lower values indicate restrictions on movements of capital flows.

The variable "EXPC" is the indicator of export concentration. It represents either export product concentration, denoted "EPC" or services export concentration, denoted "SEC". The indicator "EPC" represents the Theil index of export product concentration. It has been computed by the IMF using the definitions and methods employed by Cadot et al. (2011). The indicator "SEC" is the Theil index of services export concentration, which has also been calculated following the approach in Cadot et al. (2011) (see studies by Gnangnon, 2020a,c,d,e that have utilized this indicator in the analysis). The "SEC" index has been computed using data on commercial services exports extracted from the database developed by the IMF (see Loungani et al., 2017). This 
database contains data on 11 major services exports sectors at the 2-digit level. Details on the computation of these two indices are provided in Appendix 1. For both indices, higher values indicate a higher level of export concentration, while lower values reflect a greater degree of export diversification, including more homogeneously distributed among a series of products or services items.

To avoid unit of measurements problems relating to the various variables used in the analysis, we have standardized all variables contained in model (1). The standardization procedure involves calculating for each variable, the ratio of the difference between the variable and its mean (average) over the standard deviation of the variable. As we will see later, this procedure allows identifying which factors among those included in model (1), contribute the most and the least to the dynamics of financial openness across countries in the full sample. Additionally, as we will see later, it helps overcome outliers problems.

We report the descriptive statistics unstandardized (i.e., non-transformed variables) and standardized variables respectively in in Appendices 2a and 2b. Appendices 3 and 4 show respectively the list of countries contained in the full sample, and the list of sub-samples in this sample. Specially, the analysis has considered three main sub-samples, including high-income countries ("HICs") (derived from countries' classification of the World Bank), other countries in the full sample, referred to as "NonHICs" (which we qualify as "developing countries"). The third sub-sample is the group of least developed countries (within the sub-sample of developing countries) that we qualify as "LDCs". The focus on LDCs is dictated by the fact that the United Nations have designated countries contained in this group as the poorest and most vulnerable countries in the world. One major characteristic of this group is the high reliance of countries' exports structure on primary commodities (for goods) and tourism and transport (for services) (e.g., WTO, 2019). Therefore, it can be interesting to consider how LDCs' level of export diversification (for both goods and services) matters for their degree of financial openness.

\section{Data analysis}

We show in Figures 1 to 6 different pictures on the relationship between export diversification and financial openness. Figure 1 presents the development of export diversification and financial openness over the full sample and the sub-sample of HICs. Figure 2 does the same for the sub-samples of NonHICs and LDCs. Figures 3 to 6 show the correlation patterns between export diversification and financial openness respectively over the full sample as well as each of the three sub-samples.

\section{[Insert Figure 1, here]}

Figure 1 shows that for both the full sample and HICs, the level of financial openness has increased over time from 1985-1989 to 2005-2009, and then becomes relatively stable from 20052009 to 2010-2014. Over the full period, the degree of financial openness has remained lower in HICs than in the full sample. In the meantime, services export concentration has exhibited an upward trend over the full sample and HICs, thereby reflecting a tendency for greater concentration on a relatively limited services export items, over time. Export product concentration has fluctuated, but tends to increase over the period 2005-2009 to 2010-2014. Note that from 1985-1989 to 1995-1999, the level of export product concentration has been higher in the full sample than in HICs. However, from 2002-2004 onwards, HICs have exhibited a higher 
degree of export product concentration (probably on higher quality products) that the entire sample.

\section{[Insert Figure 2, here]}

We note from Figure 2 that in both developing countries (i.e., NonHICs) and LDCs, export product concentration has increased from 1985-1989 to 1995-1999, and then decreased up to the end of the period (which reflects a tendency for greater export diversification since 1999). However, from 1995-1999 to 2010-2014, LDCs have experienced a lower level of export product concentration than developing countries, while it is the reverse during the period running from 1985-1989 to 1995-1999. The services export concentration indicator has displayed an upward trend in both developing countries and LDCs, but remained consistently higher in developing countries than in LDCs, although towards the end of the period, both sub-samples have exhibited almost similar degrees of services export concentration. At the same time, the degree of capital account liberalization in both developing countries and LDCs has increased over time, but tends to slightly decline towards the end of the period. However, apart from the beginning of the period where it is slightly higher in LDCs than in developing countries, it has been higher in developing countries than in LDCs over the rest of the period.

The comparison between Figures 1 and 2 indicates that the degree of capital account liberalization is higher in HICs than in other countries in the full sample. Export product diversification has moved differently in HICs and developing countries, in particular from 20002004 to the end of the period. From 2000-2004 to 2010-2014, it tends to be higher in HICs than in developing countries (and hence than in LDCs). However, services export concentration level tends to be higher in developing countries (and LDCs) than in HICs, especially from 2000-2004 to 2010-2014. This reflects the fact that over these sub-periods, HICs have diversified more their services export baskets than developing countries and LDCs.

\section{[Insert Figure 3, here] \\ [Insert Figure 4, here] \\ [Insert Figure 5, here] \\ [Insert Figure 6, here]}

Figures 3 to 6 show that the graphs based on standardized variables (see the right-hand side graphs of each Figure) address outliers that appear in the left-hand side graphs that are based on unstandardized variables. The analysis of Figures 3 to 6, therefore, focuses on the right-hand side graphs of each Figure. The right-hand side graphs of Figure 3 indicates a slightly positive correlation pattern between services export concentration and financial openness, while the correlation pattern between export product concentration and financial openness is unclear. The right-hand side graphs of Figure 4 shows slightly positive correlation patterns between each export concentration indicator and financial openness in HICs. However, for developing countries, export product concentration is negatively correlated with financial openness (i.e., export product diversification is positively correlated with financial openness), while services export concentration is positively correlated with financial openness. Finally, in LDCs, there is a strong positive correlation between export product concentration and financial openness, while the correlation pattern between services export concentration and financial openness seems to be slightly negative. 


\section{Econometric approach}

We estimate model (1) using the Blundell and Bond (1998)'s two-step system Generalized Methods of Moments (GMM) estimator. This estimator is particularly suitable for this model not only because of the strong persistence nature of the dependent variable (as well as other regressors in the model), but also because of the endogeneity of many regressors in model (1). This endogeneity problem can arise from measurement errors of variables, but more importantly from the reverse causality from the dependent variable to those regressors. The latter include the export diversification variables, and well as inflation, financial development, human capital, trade openness, and democracy variables. For example, one could postulate that financial openness can influence export diversification variables through its effect on FDI inflows. These FDI inflows could also affect human capital (e.g., Nagel et al., 2015), and hence generates the endogeneity of the human capital variable. Similarly, by driving in capital flows, greater financial openness can generate inflationary pressures. Financial openness usually goes hand in hand with trade openness, which signifies that while we expect greater trade openness to induce a higher level of financial openness, it is also possible that financial openness, in turn, positively affects trade openness. Similarly, financial openness plays an important role in countries' financial development path (e.g., Baltagi et al., 2009; Ozkok 2015), hence the reverse causality can arise from the financial openness variable to the financial development variable. Finally, while we expect greater democratization to affect financial openness, the reverse causality arises from the fact that financial openness can affect the level of democracy (e.g., Li and Reuveny, 2003; Rudra, 2005; Sun, 2014).

The use of the two-step system GMM technique entails estimating a system of equations with an equation in differences, and an equation in levels. Lagged first differences are used as instruments for the levels equation, and lagged levels are used as instruments for the firstdifference equation. This estimator is more efficient than the first-differenced GMM estimator proposed by Arellano and Bond (1991) when variables display a high persistence over time (as it is the case for variables in model (1)), as in such a case, the first-differenced GMM estimator produces weak instruments. Furthermore, the two-step system GMM estimator performs better than the first-differenced GMM estimator when the panel dataset at hand is unbalanced, as in such a case, the unbalance nature of the panel dataset magnifies gaps (e.g., Roodman, 2009). Finally, the two-step system GMM estimator allows addressing the bias that would result from the correlation between the one-period lag of the dependent variable and the error term if the model (1) were to be estimated using for example the fixed effects approach.

We evaluate the appropriateness of the two-step system GMM estimator for estimating model (1) or its different variants (described later) using standard diagnostic tests. These include the Arellano-Bond test of first-order serial correlation in the error term (AR(1)), the ArellanoBond test of no second-order autocorrelation in the error term (denoted AR(2)), and the SarganHansen test of over-identifying restrictions (OID), the latter being useful in evaluating the validity of the instruments used in the regressions. Even not required, the results of the Arellano-Bond test of no third-order autocorrelation in the error term (denoted $\mathrm{AR}(3)$ ) are also reported, as the non-rejection of this hypothesis may reflect the absence of omitted variable problem. We also ensure that there is no proliferation of instruments in the regressions as otherwise, the diagnostic tests may become powerless. We have used in the different regressions a maximum of 3 lags of 
the dependent variable as instruments, and 2 lags of endogenous variables as instruments so as to meet the requirements of the two-step system GMM estimator.

Several regressions of model (1) have been performed, including to test hypotheses 1 to 3 set out in section 2. Column [1] of Table 1 reports the estimates arising from the estimation of model (1). In columns [2] and [3] of the same Table, we display the outcomes that allow examining the effect of export diversification on financial openness across the sub-samples. To obtain these outcomes, we construct two dummies for each sub-sample HICs and LDCs. For the former, the dummy is denoted "HIC", and takes the value ' 1 ' for HICs, and ' 0 ', otherwise. For LDCs, the dummy is denoted "LDC", and takes the value ' 1 ' for LDCs, and ' 0 ' for other countries in the full sample. Thus, we estimate two different specifications of model (1). The first specification of this model is model (1) in which we introduce the dummy HIC alongside its interaction with each of the export concentration indicators. This model specification helps examine the effect of export concentration in financial openness in HICs versus NonHICs, i.e., developing countries. The second specification of this model is model (1) in which we introduce the dummy LDC alongside its interaction with each of the export concentration indicators. Column [4] of Table 1 contains the results of the estimation of a specification of model (1) in which we interact the real per capita income with each of the two export diversification variables. These results help to examine the extent to which the effect of export diversification on financial openness depends on countries' level of real per capita income.

Columns [1] and [2] of Table 2 contain results that allow testing the hypothesis 2, i.e, whether the effect of export diversification on financial openness translates through the external shocks channel. Specially, results reported in column [1] of Table 2 are obtained by estimating a specification of model (1) that includes an external shock variable, as well as the interaction between this variable and each export concentration variable. The external shocks variable is proxied by the exchange rate pressure, which reflects the extent of export demand and foreign financial flows shocks that affect economies. This proxy for external shocks has been widely used in the empirical macroeconomic literature (e.g., Aizenman and Hutchison, 2012; Berg and Patillo 1999; Gnangnon, 2020f; Kaminsky et al. 1998; Morrissey et al., 2016; Patnaik et al., 2017). The shock pressure, which is the exchange rate pressure is computed (using the annual data over the period 1980-2014) as follows: $\mathrm{SHOCK}_{\mathrm{it}}=w_{E, i} \frac{\Delta E_{i t}}{E_{i, t-1}}-w_{R E S, i} \frac{\Delta R E S_{i t}}{R E S_{i, t-1}}(2) . " E^{\prime \prime}$ is the exchange rate in local currency units per USD; "RES" is the size of reserves, $w_{E, i}$ and $w_{R E S, i}$ are countryspecific weights: $w_{E, i}=\frac{\sigma_{R E S, i}}{\sigma_{R E S, i}+\sigma_{E, i}}$ and $w_{R E S, i}=\frac{\sigma_{E, i}}{\sigma_{R E S, i}+\sigma_{E, i}}(2) . \sigma_{R E S, i}$ stands for the standard deviation of $\frac{\Delta R E S_{i t}}{R E S_{i, t-1}}$ over the full period of the analysis (here, 1980-2014). Similarly, $\sigma_{E, i}$ is the standard deviation of $\frac{\Delta E_{i t}}{E_{i, t-1}}$ over the full period of the analysis (here, 1980-2014). The increase in the values of the "SHOCK" indicator indicate an increase in the extent of external shocks, while lower values of this indicator reflect lower extent of external shocks. Formula (2) indicates that in response to an adverse balance of payment shock, a country can adopt different policy measures, including a devaluation of its currency, or the use of its international reserves to defend the exchange rate (Morrissey et al., 2016). The weights used in equation (2) are country-specific and have been chosen so as to allow the smaller weight to the more volatile series. The two components of equation (2) are proxies of the magnitude of external shocks (see Morrissey et al. 2016). The 
"SHOCK" variable is considered as exogenous in this model specification, while the interaction variables are considered as endogenous.

Outcomes in column [2] of Table 2 arise from the estimation of a variant of model (1) in which we introduce the variable capturing the volatility of economic growth and its interaction with each export concentration variable. Economic growth volatility captures here the extent to which shocks affect economies, but not necessarily the only extent of shocks, as domestic shocks such as environmental shocks can also induce greater economic volatility. Note that the economic growth volatility, denoted "GRVOL" and the interaction variables are considered as endogenous in this variant of model (1). The endogeneity of the economic growth volatility variable is explained by the fact that greater financial openness (and the resulting higher capital inflows) can increase countries' macroeconomic volatility, and hence a higher economic growth volatility. The economic growth volatility variable has been calculated as the standard deviation of annual economic growth rate (growth rate of real GDP) over each of the non-overlapping sub-periods of 5-year.

Column [3] of Table 2 reports the estimations' outcomes that allow testing hypothesis 3, i.e., whether (and to what extent) the effect of export diversification on financial openness passes through the economic growth performance channel. These outcomes are obtained by estimating another variant of model (1) that contains the real economic growth variable ('denoted "GROWTH") and its interaction with each of the two indicators of export concentration. Both the economic growth variable and the interaction variables are treated as endogenous. The endogeneity of the economic growth variable is explained by the fact that financial openness itself influences countries' economic growth ${ }^{10}$ (e.g., Edison et al. 2002; Klein and Olivei, 2008; Kunieda et al., 2014; Singh, 2003).

\section{Interpretation of estimations' outcomes}

The outcomes related to the diagnostic tests to assess the consistency of the two-step system GMM approach are reported at the bottom of all columns in Tables 1 and 2. They show that all the requirements of the two-step system GMM are met. The p-values related to the AR(2), AR (3) tests as well as the OID test are, as expected, higher than 0.10. The p-values associated with the $\mathrm{AR}(1)$ test are lower than 0.10 . Furthermore, the one-period lag of the financial openness has shown a positive and significant (at the $1 \%$ level) coefficient across all columns of the two Tables. This underlines the existence an inertia in the capital policy reform.

\section{[Insert Table 1, here]}

Results in column [1] of Table 1 show negative and significant (at the $1 \%$ level) coefficients for the two indicators of export concentration. This signifies that export product concentration and services export concentration are negatively associated with financial openness. In other words, export product diversification and services export diversification exert a positive effect on financial openness. These findings run against bypothesis 1 (while supporting bypotheses $2 \& 3$ ), and suggest that, on average across the full sample, it is the diversification of export product basket and of services items that leads policymakers to further open-up the capital account. However, as we will see in columns [2] and [3] of Table 1, these findings reflect different effects of export diversification on financial openness across countries in the full sample. From column [1] of Table

${ }^{10}$ Nevertheless, Grilli and Milesi-Ferreti (1995) have reported no significant effect of capital account liberalization and economic growth. 
1 , we note that an increase in the index of export product concentration and the index of services export concentration by a one standard deviation leads to a fall in the index of financial openness respectively by a 0.136 standard deviation and a 0.075 standard deviation. These outcomes also indicate that, on average, over the full sample, export product diversification exerts a higher positive effect on financial openness than does services export diversification. Outcomes related to control variables are to a larger extent similar across the four columns of Table 1. Focusing on those in column [1] of Table 1, we find that lower inflation, greater financial development, and lower population size influence positively financial openness. Trade openness exerts no significant effect on financial openness at the conventional levels, while greater democratization appears to influence negatively and significantly financial openness. Also, countries that accumulate higher levels of human capital tend to open less their capital account than countries with lower levels of human capital accumulated. This may be explained by the fact that countries that experience a relatively low level of human capital further open-up their capital account so as to attract capital flows, including FDI inflows, which, in turn, can help enhance knowledge and skills, and thus contribute to accumulating human capital (e.g., Nagel et al., 2015; Zhuang, 2017). The real per capita income appears to be negatively and significantly related to financial openness. This runs against our expectation set out in section 3 , and suggests that less developed countries tend to experience a higher level of financial openness than relatively more advanced countries. It is worth noting that authors such as Steinberg et al. (2018) have also obtained a negative effect of the real per capita income on financial openness. When it comes to ranking the variables that exhibit significant coefficients (at the conventional levels) in column [1] of Table 1, we observe (in terms of absolute value) that the inflation rate appears to be the variable that contributes the most to changes in financial openness. The services export concentration indicator contributes the least to the dynamics of financial openness. The inflation rate is followed by the population size, the financial development, export product concentration, human capital, the level of democratization, and the real per capita income. From these, we conclude that among determinants of financial openness under analysis here, export product diversification appears in the middle (in terms of ranking) of the list of those determinants, while services export concentration contributes the least to the dynamics of financial openness.

Turning to results in column [2] of Table 1, we obtain that at the 1\% level, export product concentration exerts a higher positive effect on financial openness in HICs than in developing countries. At the same time, services export concentration exerts a higher positive effect on financial openness in HICs than in developing countries, also at the $1 \%$ level. Therefore, these outcomes suggest that at the $1 \%$ level, the net effect of export product concentration on financial openness in HICs amounts to $+0.08(=-0.247+0.330)$, and the net effect of services export concentration on financial openness in HICs amounts to $+0.1(=-0.136+0.236)$. These findings indicate that on average in HICs, both export product concentration and services export concentration influence positively financial openness, with the magnitude of the effect of services export diversification on financial openness being slightly higher than that of export product diversification. In contrast, in developing countries, the net effects of export product concentration and services export concentration on financial openness amount respectively to 0.247 and -0.136 . Thus, both export product diversification and services export diversification influence positively financial openness in developing countries, and the effect of the latter is higher than that of the former. 
Results in column [3] of Table 1 show that the coefficient of "EPC" and the interaction term of the interaction variable "EPC*LDC" are both significant at the $1 \%$, while respectively negative, and positive. These signify that export product concentration exerts a higher effect on financial openness in LDCs than in other countries in the full sample. But, the net effect of export product concentration on financial openness in LDCs is given by $-0.02(=-0.175+0.157)$. We deduce that greater export product diversification exerts a positive effect on financial openness in LDCs. However, as per relevant results in column [3] of the same Table, we find no significant effect of services export concentration on financial openness in LDCs.

Outcomes in column [3] suggest negative and significant coefficients (at the 1\% level) of the variables "EPC" and "SEC", and positive and significant coefficients (at the 1\% level) of the interaction variables "EPC*GDPC" and "SEC*GDPC". These results reveal that as countries enjoy a higher real per capita income, they tend to experience a positive effect of export concentration (for both products and services) on financial openness. In other words, there is a threshold of real per capita income above which the total effects of export product concentration and services export concentration on financial openness become positive (as below this threshold, the effects are negative). Hence, export product concentration exerts a positive effect on financial openness when the standardized value of the real per capita income is higher than 1.81 (= $0.170 / 0.0940$ ) or equivalently if the unstandardized real per capita income is higher than US\$ $43171.9(=12557.09+16914.26 * 1.81)$ (note that 12557.09 and 16914.26 are respectively the mean and the standard deviation of the real per capita income in the full sample - see Appendix 2a). It is also worth recalling that values of the real per capita income range between US\$226.4 and US\$ 89835.2 (see Appendix 2a), and the threshold US\$ 43171.9 falls within this range of values. Summing-up, for countries whose real per capita income is lower than US\$43171.9, export product diversification drives positively financial openness, and the lower the real per capita income, the higher is the magnitude of the positive effect of export product diversification on financial openness. In contrast, in countries that experience a real per capita income lower than US\$ 43171.9, export product concentration influences positively financial openness. For this set of countries, the magnitude of the positive effect of export product concentration on financial openness rises with the real per capita income. Thus, export product concentration influences positively financial openness for countries with a very high real per capita income. In countries with a relatively lower real per capita income (for example, in developing countries, including poor countries), it is export product diversification that drives positively financial openness.

The same reasoning (as above) unfolds for the effect of services export concentration on financial openness for varying values of the real per capita income: here, the threshold of the real per capita income above which (below which) services export concentration (services export diversification) affects positively financial openness is different from the one obtained above for export product diversification. The standardized value of this threshold amounts to 1.23 (= $0.0798 / 0.0648$ ), and equivalently, the unstandardized real per capita income is US\$ 33361.6 (= $12557.09+16914.26 * 1.23)$. Thus, in countries with a real per capita income lower than US\$ 33361.6 (these include developing countries), services export diversification exerts a positive effect on financial openness, and within this set of countries, the greater the real per capita income, the higher is the magnitude of the positive effect of services export diversification on financial openness. Conversely, countries with a real per capita income lower than US\$33361.6 experience a positive effect of services export concentration on financial openness, and the lower the real per 
capita income, the greater is the magnitude of the positive effect of services export concentration on financial openness. Overall, hypothesis 1 holds for export products in countries with a real per capita income than US\$43171.9, and for services exports, in countries with a real per capita income higher than US\$33361.6.

\section{[Insert Table 2, here]}

We now examine results in Table 2 that help test hypotheses 2 and 3 . We note that the variables "EPC" and "EPC*SHOCK" hold negative and significant coefficients (at the 1\% level). These outcomes suggest that the effect of export product concentration on financial openness genuinely depends on the size of external shocks, as the greater the size of these shocks, the higher is the magnitude of the negative effect of export product concentration on financial openness. Put differently, export product diversification exerts a positive effect on financial openness in the presence of external shocks, and the higher the size of external shocks, the greater is the magnitude of the positive effect of export product diversification on financial openness. These show that countries that diversify their export product baskets are much more able (than countries that experience a high degree of export product concentration) to maintain an open capital account when experiencing external shocks. These findings are confirmed in column [2] of Table 2, because both the variables "EPC" and "EPC*GRVOL" hold negative and significant coefficients at the $1 \%$ level. Hence, export product concentration (diversification) influences negatively (positively) financial openness in the context of greater economic growth volatility, and the greater the level of the economic growth volatility, the higher is the magnitude of the negative (positive) effect of export product concentration (diversification) on financial openness.

In the meantime, in column [1] of Table 2, the coefficient of the variable "SEC" is not significant at the conventional levels, while the interaction variable "SEC*SHOCK" has shown a positive and significant coefficient at the $1 \%$ level. Thus, in the context of external shocks, services export concentration induces a greater financial openness. These findings are confirmed by the outcomes reported in column [2] of Table 2, at least when the level of economic growth volatility reaches a certain threshold. In fact, the coefficient of "SEC" is positive and significant at the $1 \%$ level, while the interaction term related to the variable "SEC*GRVOL" is negative and significant at the $5 \%$ level. Thus, the standardized value of the threshold of "GRVOL" above which services export concentration induces greater financial openness is given by $1.63(=0.102 / 0.0624)$. Equivalently, the unstandardized value of the threshold of "GRVOL" amounts to 6.4 [ $=2.696+$ $2.287 * 1.63$ ] (2.696 and 2.287 are respectively the mean and standard deviation of the economic growth volatility in the full sample - and values of this variable range between 0.24 and 22.24 . See Appendix 2a). For economic growth volatility levels lower than 6.4, services export diversification is positively associated with financial openness, while for degrees of economic growth volatility higher than 6.4, it is rather services export concentration that induces greater financial openness.

Overall, export product diversification tends to be positively associated with financial openness when countries experience higher sizes of shocks, while services export concentration promotes financial openness in the context of high extent of external shocks. These findings may suggest that that export product diversification and services export diversification are substitutable in influencing countries' degree of capital account openness when they are prone to a higher extent of external shocks. We test this hypothesis later.

Taking-up the results in column [3] of Table 1, we find that the variables "EPC" and "SEC" hold negative and significant coefficients (at the 1\% level), while the interaction term related to the 
variable "EPC*GROWTH" is negative and significant at the $1 \%$ level, and the one associated with the variable "EPC*GROWTH" is also negative and significant at the 5\% level. These outcomes indicate that the effect of export diversification on financial openness depends on countries' economic growth performance. Regardless of countries' economic growth performance, export diversification (for both products and services) always induces greater financial openness. Additionally, the higher the economic growth performance, the greater is the magnitude of the positive effect of both export product diversification and services export diversification on financial openness.

Control variables across the three columns of Table 2 have shown results that align with those in column [1] of Table 1.

\section{Further analysis}

The analysis above has suggested, inter alia, that there may be an interaction between the effects of export product diversification and services export diversification on financial openness when countries face a greater extent of external shocks. This section tests this hypothesis. We start by estimating a version of model (1) in which we include the variable representing the interaction between the two indicators of export product concentration. The results of the estimation of this specification of model (1) by means of the two-step system GMM estimator are reported in column [1] of Table 3.

Second, we explore the extent to which export product concentration and services export concentration interact in influencing financial openness as countries experience a higher size of external shocks. To that effect, we estimate another variant of model (1) in which we include the variable "SHOCK" as well as a series of interaction variables. The latter include the interaction between the two indicators of export concentration, the interaction between each indicator of export concentration and the external shocks variable, the interaction between export product concentration, services export concentration and the external shocks variables. We are interested here in the coefficient of the interaction between export product concentration, services export concentration and the external shocks variable, and the coefficient of the interaction between the two indicators of export concentration. The results of the estimation of this new variant of model (1) are provided in column [2] of Table 3.

\section{[Insert Table 3, here]}

In the two columns of Table 3, we find that all requirements of the two-step system GMM estimator are met. Additionally, the coefficient of the one-period lag of the financial openness is positive and significant at the $1 \%$ level. These outcomes confirm the appropriateness of the twostep system GMM estimator for estimating the two variants of model (1) described in the present section.

We first note from column [1] of Table 3 that the interaction term of the variable "EPC*SEC" is negative and significant at the $1 \%$ level. At the same time, the coefficient of "SEC" is not significant at the conventional levels, while the coefficient of "EPC" is negative and significant at the 5\% level. Taken together, these outcomes suggest that export product concentration and services export product concentration genuinely interact in influencing financial openness. Specially, the effects of these two variables are substitutable in influencing financial openness. In other words, services export diversification exerts a positive effect on financial 
openness in countries with a high level of export product concentration, and vice versa. Moreover, the greater the degree of export product concentration, the higher is the magnitude of the positive effect of services export diversification on financial openness.

Results in column [2] of Table 3 indicate negative and significant (at the 1\% level) interaction terms related respectively to the variables "EPC*SEC" and "EPC*SEC*SHOCK". Therefore, we conclude that the degree of capital account openness decreases in countries that experience a high level of both export product concentration and services export concentration, in the context of external shocks. However, when facing external shock, countries experience a rise in their level of financial openness when they either diversify their export product (while experiencing a high services export concentration) or when they diversify their services export items (in the presence of higher export product concentration). Overall, export product concentration and services export concentration are substitutable in positively driving financial openness in the context of higher extent of external shocks.

\section{Conclusion}

This paper has considered the effect of export diversification (i.e., both export product diversification and services export diversification) on financial openness. The analysis has been conducted using a sample of 119 countries (both developed and developing countries) over the period 1985-2014. The findings are interesting. We obtain that over the full sample, both export product diversification and services export diversification exert a positive effect on financial openness. However, this later result reflects a positive effect of export product concentration and services export concentration on financial openness in countries with high real per capita incomes, while in countries with a relatively lower real per capita income (these include developing countries), export product diversification and services export diversification influence positively financial openness.

We also obtain that export product diversification and services export diversification are substitutable in influencing financial openness, including in the context of external shocks. In particular, in the context of greater external shocks, countries open-up their financial account when they experience either a higher level of export product diversification (and a low degree of services export product diversification) or when the level of export product concentration (whilst that of services export concentration is low, i.e., the degree of services export diversification is high). Interestingly, export product diversification and services export diversification induces greater financial openness when countries experience a higher economic growth performance.

Overall, these findings contribute to the literature on the macroeconomic determinants of financial openness, and particularly on the link between international trade and financial openness, by showing clearly that both export product diversification and services export diversification matter for financial openness dynamics. Furthermore, their effect on financial openness depends on the extent of external shocks that affect countries, as well as their economic growth performance. 


\section{References}

Abraham, F., and Schmukler, S.L. (2017). Financial globalization: a glass half empty? Policy Research Working Paper Series 8194, The World Bank, Washington, D.C.

Acemoglu, D., and Zilibotti, F. (1997). Was prometheus unbound by chance? Risk, diversification, and growth. Journal of Political Economy, 105(4), 709-51.

Aditya, A., and Acharyya, R. (2013). Export Diversification, Composition, and Economic Growth: Evidence from Cross-country Analysis. Journal of International Trade and Economic Development 22, 959-992.

Agénor, P-R. (2003). Benefits and Costs of International Financial Integration: Theory and Facts. The World Economy, 26(8), 1089-1118.

Aghion, P., Bacchetta, P., and Banerjiee, A. (2004). Financial development and the instability of open economies. Journal of Monetary Economics, 51(6), 1077-1106.

Agosin, R., Alvarez, R., and Bravo-Ortega, C. (2012). Determinants of Export Diversification around the World: 1962-2000. The World Economy, 35(3), 295-315.

Aguiar, M., and Gopinath, G. (2007). Emerging Markets Business Cycles: The Cycle is the Trend. Journal of Political Economy, 115(1), 11-69.

Ahmed, S., and Zlate, A. (2014). Capital Flows to Emerging Market Economies: A Brave New World? Journal of International Money and Finance, 48, 221-248.

Aizenman, J., and Hutchison, M. M. (2012). Exchange market pressure and absorption by international reserves: Emerging markets and fear of reserve loss during the 2008-2009 crisis. Journal of International Money and Finance, 31, 1076-1091.

Álvarez, R., García-Marín, A., Ilabaca, S. (2018). Commodity price shocks and poverty reduction in Chile. Resources Policy, See online at: https://doi.org/10.1016/j.resourpol.2018.04.004

Anand, R., Mishra, S., and Spatafora, N. (2012). Structural Transformation and the Sophistication of Production. IMF Working Paper, WP/12/59. International Monetary Fund, Washington, D.C.

Arestis, P., Basu, S., and Mallick, S. (2005). Financial Globalization: The Need for a Single Currency and a Global Central Bank. Journal of Post Keynesian Economics, 27(3), 507-531.

Ariu, A. (2016). Crisis-Proof Services Why Trade in Services Did Not Suffer During the 20082009 Collapse. Journal of International Economics, 98, 138-149.

Arellano, M., and Bond, S. (1991). Some Tests of Specification for Panel Data: Monte Carlo Evidence and an Application to Employment Equations. Review of Economic Studies, 58, 277297.

Artis, M. J., and, Hoffmann, M. (2007). Declining home bias and the increase in international risk sharing: lessons from European integration. CEPR discussion papers 6617, 1-29. Accessed 20 Sep 2010 . 
Asheghian, P., and Saidi, R. (2002). Commodity Concentration and Export Earning Instability: The Case of Venezuela. Development Policy Review, 17(4), 419-427.

Athukorola, P. C. (2000). Manufacturing exports and terms of trade of developing countries: evidence from Sri Lanka. Journal of Development Studies, 36, 89-104.

Bacchetta, M., Jansen, M., Piermartini, R. and Amurgo-Pacheco, R. (2007). Export Diversification as an Absorber of External Shocks. World Trade Organization, Mimeo, Switzerland.

Bai, Y., and Zhang, J. (2006) Financial integration and international risk sharing. Society for economic dynamics 2006 meeting paper 371, pp 1-31. http://ideas .repec .org/p/red/sed00 6/371.html. Accessed 30 Nov 2009.

Baker, H., Nofsinger, J. and Weaver, D. (2002). International Cross-Listing and Visibility. Journal of Financial and Quantitative Analysis, 37(3), 495-521.

Balavac, M., and Pugh, G. (2016). The link between trade openness, export diversification, institutions and output volatility in transition countries. Economic Systems, 40(2), 273-287.

Ball, R., Hail, L., and Vasvari, F. (2018). Equity Cross-Listings in the U.S. and the Price of Debt. Review of Accounting Studies, 23(2), 385-421.

Baltagi, B. H., Demetriades, P. O., and Law, S. H. (2009). Financial development and openness: evidence from panel data. Journal of Development Economics, 89, 285-296.

Bancel, F., and Mittoo, R. (2001). European Managerial Perceptions of the Net Benefits of Foreign Stock Listings. European Financial Management, 7(2), 213-36.

Basile, R., and Girardi, A. (2010). Specialization and risk sharing in European regions. Journal of Economic Geography, 10(5), 645-659.

Bekaert, G., and Harvey, C. (1997). Emerging equity market volatility. Journal of financial economics, 43, 29-77.

Bekaert, G., and Harvey, C.R. (2000). Foreign speculators and emerging equity markets. Journal of Finance, 55, 565-614.

Bekaert, G., Harvey, C., and Lundblad, C. (2005). Does Financial Liberalization Spur Growth?. Journal of Financial Economics, 77, 3-55.

Benos, E., and Weisbach, M. (2004). Private Benefits and Cross-listings in the United States. Emerging Markets Review, 5(2), 217-240.

Berg, A., and Pattillo, C. (1999). Predicting currency crises: the indicators approach and an alternative, Journal of International Money and Finance, 18 (4), 561-586.

Borchert, I., and Mattoo, A. (2010). The crisis-resilience of services trade. The Service Industries Journal, 30(13), 2115-2136. 
Bos, J.W.B., Economidou, C., and Zhang, L. (2020). Specialization in the presence of trade and financial openness. Empirical Economics 58, 2783-2816.

Blundell, R., and Bond, S. (1998). Initial Conditions and Moment Restrictions in Dynamic Panel Data Models. Journal of Econometrics, 87, 115-143.

Buch, C.M., Doepke, J., and Pierdzioch, C. (2005). Financial openness and business cycle volatility. Journal of International Money and Finance, 24(5), 744-765.

Cadot, O., Carrere, C., and Strauss-Kahn, V. (2011). Export Diversification: What's Behind the Hump? Review of Economics and Statistic, 93, 590-605.

Calvo, G. (1996). Inflows of capital to developing countries in the 1990s. Journal of Economic Perspectives, 10, 123-139.

Calvo, G.A., Leiderman, L. and Reinhart, C.M. (1993). Capital Inflows and Real Exchange Rate Appreciation in Latin America: the Role of External Factors. IMF Staff Papers, 40(1),108-151.

Camanho da Costa Neto, N., and Romeu, R. (2011). Did export diversification soften the impact of the global financial crisis?. International Monetary Fund Working Paper WP/11/99, International Monetary Fund, Washington, D.C.

Can, M., and Gozgor, G. (2017). Causal Linkages among the Product Diversification of Exports, Economic Globalization and Economic Growth. Review of Development Economics, 21(3), 888908.

Cariolle, J., Goujon, M., and Guillaumont, P. (2016). Has Structural Economic Vulnerability Decreased in Least Developed Countries? Lessons Drawn from Retrospective Indices. The Journal of Development Studies, 52(5), 591-606.

Chakrabarti, A. (2001). The determinants of foreign direct investment: Sensitivity analyses of cross-country regressions. Kyklos, 54(1), 89-114.

Chinn, M. D. and Ito, H. (2006). What Matters for Financial Development? Capital Controls, Institutions, and Interactions. Journal of Development Economics, 81(1), 163-192.

Chouinard, E., and D'Souza, C. (2004). The Rationale for Cross-Border Listings. Bank of Canada Review, 2003-2004 (Winter), 23-30.

Claessens, S.-K.A., and Huizinga, H. (2001). How does foreign entry affect domestic banking markets?. Journal of Banking and Finance, 25(5), 891-911.

Dabla-Norris, E., and Gündüz, Y. B. (2014). Exogenous Shocks and Growth Crises in LowIncome Countries: A Vulnerability Index. World Development, 59, 360-378.

De Benedictis, L., Gallegati, M. and Tamberi, M. (2003). Non-Linearities in Specialization and Growth. Available from http://ssrn.com/abstract $=412260$.

De Pineres S. and Ferrantino M. (1997). Export diversification and structural dynamics in the growth process: The case of Chile. Journal of Development Economics, 52(2), 375-391. 
di Giovanni, J., Levchenko, A., and Méjean, M. (2014). Firms, destinations and aggregate fluctuations. Econometrica, 82(4),1303-1340.

Eckel, C. (2008). Globalization and specialization. Journal of International Economics, 75(1), 219228.

Eaton, J., and Tamura, A. (1994). Bilateralism and Regionalism in Japanese and U.S. Trade and Direct Foreign Investment Patterns. Journal of the Japanese and International Economies, 8(4), 478-510.

Edison, H.J., Levine, R., Ricci, L., and Sløk, T. (2002). International Financial Integration and Economic Growth. Journal of International Money and Finance, 21(6), 749-776.

Eichengreen, B. (2001). Capital Account Liberalization: What Do Cross-Country Studies Tell Us? World Bank Economic Review, 15, 341-65.

Eichengreen, B., and Leblang, D. (2003). Capital Account Liberalization and Growth: Was Mr. Mahathir Right?. International Journal of Finance and Economics, 8(3), 205-224.

Essers, D. (2013). Developing country vulnerability in light of the global financial crisis: Shock therapy? Review of Development Finance, 3(2), 61-83.

Feenstra, R. C., Inklaar, R., and Timmer, M.P. (2015). The Next Generation of the Penn World Table. American Economic Review, 105(10), 3150-3182.

Fernandez-Arias, E. and Montiel, P. (1996). The Surge in Capital Inflows to Developing Countries: An Analytical Overview. World Bank Economic Review, 10(1), 51-77.

Fratzscher, M. (2012). Capital flows, push versus pull factors and the global financial crisis. Journal of International Economics, 88(2), 341-356.

Gallagher, K. P. (2015). Ruling capital: Emerging markets and the reregulation of cross-border finance. Ithaca, NY: Cornell University Press.

Ghosh, A.R., Qureshi, M. S. Kim, J. and Zalduendo, J. (2014). Surges. Journal of International Economics, 92(2), 266-85.

Gluzmann, P., and Guzman, M. (2017). Assessing the robustness of the relationship between financial reforms and banking crises. Journal of International Financial Markets, Institutions and Money, 49, 32-47.

Gnangnon, S.K. (2019). Multilateral Trade Liberalisation and Financial Openness. Economic Affairs, 38(3), 325-338.

Gnangnon, S.K. (2020a). Services Export Diversification and Economic Growth. Research Article, Preprint, Research Square. DOI: 10.21203/rs.3.rs-16491/v1

Gnangnon, S.K. (2020b). Services Export Diversification and Economic Growth. Accepted and forthcoming in European Journal of Comparative Economics, 2020. 
Gnangnon, S.K. (2020c). Effect of the Internet on Services Export Diversification. Journal of Economic Integration, 35(3), 519-558.

Gnangnon, S.K. (2020d). Manufacturing Exports and Services Export Diversification. International Trade Journal, published online in July 2020. https://doi.org/10.1080/08853908.2020.1779877

Gnangnon, S.K. (2020e). Aid for Trade and Services Export Diversification in RecipientCountries. Australian Economic Papers, Published online on 18 August 2020. https://doi.org/10.1111/1467-8454.12200

Gnangnon, S.K. (2020f). Exchange rate pressure, fiscal redistribution and poverty in developing countries. Economic Change and Restructuring, Published on 21 September 2020, https://doi.org/10.1007/s10644-020-09300-w

Greenwood, J., and Jovanovic, B. (1990). Financial development, growth, and the distribution of income. Journal of Political Economy, 98(5 - Part1),1076-1107.

Grilli, V, and Milesi-Ferreti, G.M. (1995). Economic Effects and Structural Determinants of capital controls » Staff paper, 22, 517-51.

Grossman, G., and Razin, A. (1985). International Capital Movements under Uncertainty. Journal of Political Economy, 92, 286-306.

Guichard, S. (2017). Findings of the recent literature on international capital flows: Implications and suggestions for further research. OECD Economics Department Working Papers, No. 1410, OECD Publishing, Paris.

Guillaumont, P. (2009). An economic vulnerability index: its design and use for international development policy. Oxford Development Studies, 37(3), 193-228.

Guillaumont, P. (2017). Vulnerability and Resilience: A Conceptual Framework applied to Three Asian Countries - Bhutan, Maldives, and Nepal. ADB South Asia Working Paper Series N53, Asian Development Bank, Philippines.

Haddad, M., Lim, J. J., Pancaro, C., and Saborowski, C. (2013). Trade openness reduces growth volatility when countries are well diversified. Canadian Journal of Economics, 46(2), 765-790.

Hannan, S.A. (2017). The Drivers of Capital Flows in Emerging Markets Post Global Financial Crisis. Journal of International Commerce, Economics and Policy, 8(2), 1-28.

Hausmann, R., Hwang, J., and Rodrik, D. (2007). What you export matters. Journal of Economic Growth, 12(1), 1-25.

Helleiner, E. (1993). Freeing Money, Restricting Trade: Explaining the Liberalization of Finance in a Protectionist Age. Presented at the 1993 annual meeting of the International Studies Association, Acapulco.

Helpman, E., and Razin, A. (1978). A Theory of International Trade under Uncertainty (New York: Academic Press, 1978). 
Henry, P.B. (2000a). Do stock market liberalizations cause investment boom? Journal of Financial Economics, 58(1-2), 301-334.

Henry, P.B. (2000b). Stock market liberalization, economic reform, and emerging market equity prices. Journal of Finance, 55(2), 529-564.

Henry, P.B. (2007). Capital Account Liberalization: Theory, Evidence, and Speculation. Journal of Economic Literature, 45(4), 887-935.

Herrmann, D., Kang, T. and Yoo, Y. (2015). The Impact of Cross-Listing in the United States on the Precision of Public and Private Information. Journal of International Business Studies, 46(1), 87-103.

Herzer, D., and Nowak-Lehmann, F. D. (2006). What Does Export Diversification Do for Growth? An Econometric Analysis. Applied Economics, 38(15), 1825-1838.

Hill, T. P. (1977). On Goods and Services. The Review of Income and Wealth, 23(4), 315-338.

Hindley, B., and Smith, A. (1984). Comparative Advantage and Trade in Services. The World Economy, 7(4), 369-390.

Imbs, J. (2004). Trade, finance, specialization, and synchronization. Review of Economics and Statistics, 86(3), 723-734.

Imbs, J. (2006). The real effects of financial integration. Journal of International Economics, 68(2), 296-324.

International Monetary Fund (IMF). (2008). Food and Fuel Prices: Recent Developments, Macroeconomic Impact, and Policy Responses. International Monetary Fund, Washington, DC. See online at: https://www.imf.org/en/Publications/Policy-Papers/Issues/2016/12/31/Foodand-Fuel-Prices-Recent-Developments-Macroeconomic-Impact-and-Policy-Responses-AnUpdate-PP4280

International Monetary Fund (IMF). (2012). The liberalization and management of capital flows: an institutional view. Washington, DC. https://www.imf.org/en/Publications/PolicyPapers/Issues/2016/12/31/The-Liberalization-and-Management-of-Capital-Flows-AnInstitutional-View-PP4720

International Monetary Fund (IMF). (2013). Low-Income Countries Global Risks and Vulnerabilities Report. International Monetary Fund, Washington, DC. See online at: https://www.imf.org/external/np/pp/eng/2013/090613.pdf

Joya, O. (2015). Growth and volatility in resource-rich countries: Does diversification help? Structural Change and Economic Dynamics, 35, 38-55.

Joyce, J.P., and Noy, I. (2008). The IMF and the Liberalization of Capital Flows. Review of International Economics, 16(3), 413-430.

Kalemli-Ozcan S, Sorensen BE, Yosha O (2004) Asymmetric shocks and risk sharing in a monetary union: updated evidence and policy implications for Europe. CEPR discussion papers 4463, pp 1-25. http:/ /ideas .repec .org/p/cpr/ceprd p/4463.html. Accessed 15 Jan 2010. 
Kalemli-Ozcan, S., Sorensen, B.E., and Yosha, O. (2003). Risk sharing and industrial specialization: regional and international evidence. American Economic Review, 93(3), 903-918.

Kaminsky, G., Lizondo, S., and Reinhart, C. (1998). Leading indicators of currency crisis. IMF Staff Papers, 45, 1-14, International Monetary Fund, Washington, D.C.

Karcher, S., and Steinberg, D.A. (2013). Assessing the Causes of Capital Account Liberalization: How Measurement Matters. Source: International Studies Quarterly, 57(1), 128-137.

Kimura, F., and Lee, H. H. (2006). The gravity equation in international trade in services. Review of World Economics, 142(1), 92-121.

Klein, M.W., and Olivei, G.P. (2008). Capital account liberalization, financial depth, and economic growth. Journal of International Money and Finance, 27(6), 861-875.

Koren, M., and Tenreyro, S. (2007). Volatility and development. Quarterly Journal of Economics, $122(1), 243-287$.

Kose, M., Prasad, E., Rogoff, K., and Wei, S-J. (2009) «Financial Globalization: A Reappraisal» International Monetary Fund, IMF Staff Papers, 56(1), 8-62.

Kose, A., Prasad, E., Rogoff, K. and Wei, S. J. (2010). Financial Globalization and Economic Policies, Handbook of Development Economics, 5, 4283-4359.

Kramarz, F., Martin, J., and Mejean, I. (2020). Volatility in the small and in the large: The lack of diversification in international trade. Journal of International Economics, 122, Article 103276.

Kunieda, T., Okada, K., and Shibata, A. (2014). Corruption, capital account liberalization, and economic growth: Theory and evidence. International Economics, 139, 80-108.

Lane, P. R., and Milesi-Ferretti, G.M. (2003). International financial Integration. Discussion Paper $\mathrm{n}^{\circ}$ 3, Institute for International Integration Studies and Economics Department, TCD and CEPR.

Lee, C.C., Lin, C.W., and Zeng, J-H. (2016). Financial liberalization, insurance market, and the likelihood of financial crises. Journal of International Money and Finance, 62, 25-51.

Lemmen, J., and Eijffinger, S. (1996). The Fundamental Determinants of Financial Integration in the European Union. Review of World Economics, 132(3), 432-456.

Levine, R., and Zervos, S. (1996). Stock market development and long-run growth, The World Bank Economic Review, 10(2), 323-339.

Li, Q., and Reuveny, R. (2003). Economic Globalization and Democracy: An Empirical Analysis, British Journal of Political Science, 33(1), 29-54.

Loungani, P., Mishra, S., Papageorgiou, C., and Wang, K. (2017). World Trade in Services: Evidence from A New Dataset. IMF Working Paper WP/17/77, International Monetary Fund, Washington, D.C. 
Love, J. (1986). Commodity concentration and export earnings instability: A shift from crosssection to time series analysis. Journal of Development Economics, 24(2), 239-248.

Love, J. (1987). Export Instability in Less Developed Countries: Consequences and Causes. Journal of Economic Studies, 14(2), 3-80.

Macbean, A. I., and Nguyen, D. T. (1980). Commodity Concentration and Export Earnings Instability: A Mathematical Analysis. The Economic Journal, 90(358), 354-362.

Malik, A., and Temple, J. R. W. (2009). The geography of output volatility. Journal of Development Economics, 90(2), 163-178.

Mania, E., and Rieber, A. (2019). Product export diversification and sustainable economic growth in developing countries. Structural Change and Economic Dynamics, 51, 138-151.

Marshall, M.G., Gurr, T.R., and Jaggers, K. (2018). Polity IV Project: Political Regime Characteristics and Transitions, 1800-2017. Centre for Systemic Peace: Vienna, VA.

Mathieson, D. J., and Rojas-Suarez, L. (1993). Liberalization of the Capital Account : Experiences and Issues. International Monetary Fund Occasional Paper Working Paper No. 92/46. Washington, DC: IMF.

Matthee, M., Idsardi, E., and Krugell W. (2016). Can South Africa sustain and diversify its exports? South African Journal of Economic and Management Sciences, 19(2), 249-263.

McIntyre, A., Li, M. X., Wang, K., and Yun, H. (2018). Economic Benefits of Export Diversification in Small States. International Monetary Fund Working Paper $N^{\circ}$ WP/18/86, Washington, D.C.

Mishra, S., Lundstrom, S., and Anand, R. (2011). Service Export Sophistication and Economic Growth. Policy Research Working Paper, WPS5606, World Bank, Washington, D.C.

Montiel, P. (1996). Policy responses to surges in capital flows: issues and lessons. In G. Calvo, M. Goldstein, \& E. Hochreiter (Eds.), Private capital flows to emerging markets after the Mexican crisis. Washington, DC: Institute for International Economics.

Morgan, W., and Snowden, N. (2007). Comparative Advantage and the Gains from Financial Trade: A Reappraisal”. The World Economy, 30(2), 342-362.

Morrissey, O., Von Haldenwang, C., Von Schiller, A., Ivanyna, M., and Bordon, I. (2016). Tax Revenue Performance and Vulnerability in Developing Countries. The Journal of Development Studies, 52(12), 1689-1703.

Moser, G, Pointner W, Scharler J (2004) Risk sharing in Europe: Has anything changed? In: Liebscher K, Christl J, Mooslechner P, Ritzberger-Grunwald D (eds) The economic potential of a larger Europe. Edward Elgar Publishing, Cheltenham, pp 260-275.

Nagel, K., Herzer, D., and Nunnenkamp, P. (2015). How Does FDI Affect Health? International Economic Journal, 29(4), 655-679. 
Naudé, W., Bosker, M., and Matthee, M. (2010). Export Specialization and Local Economic Growth. World Economy, 33(4), 552-572.

Naudé, W. A., and Rossouw, R. (2011). Export Diversification and Economic Performance: Evidence from Brazil, China, India and South Africa. Economic Change and Restructuring, 44(1), $99-134$.

Nyahoho, E. (2010). Determinants of Comparative Advantage in the International Trade of Services: An Empirical Study of the Hecksher-Ohlin Approach. Global Economy Journal, 10(1), $1-24$.

Obstfeld, M. (1994). Risk-taking, global diversification and growth. American Economic Review, 84(5), 1310-1329.

Obstfeld, M. (1998). 'The Great Depression as a watershed: International capital mobility in the long run'. In The defining moment: The Great Depression and the American economy in the twentieth century, ed. M. D. Bordo, C. D. Goldin, and E. N. White, 353-402. Chicago: University of Chicago Press.

Olson, M. (1982). The Rise and Decline of Nations. New Haven: Yale U. Press.

Ozkok, Z (2015). Financial openness and financial development: An analysis using indices. International Review of Applied Economics, 29(5), 620-649.

Patnaik, I., Felman, F., and Shah, A. (2017). An exchange market pressure measure for cross country analysis. Journal of International Money and Finance, 73, 62-77.

Pisani, M. (2011). Financial Openness and Macroeconomic Instability in Emerging Market Economies. Open Economic Review, 22, 501-532.

Portes, R., and Rey, H. (1999). The Determinants of Cross-Border Equity Flows. National Bureau of Economic Research Working Paper, no. 7336, Cambridge, MA.

Prasad, E.S., and Rajan, R.G. (2008). A Pragmatic Approach to Capital Account Liberalization. Journal of Economic Perspectives, 22(3), 149-172.

Prebisch, R. (1950). The economic development of Latin America and its principal problems. Economic Bulletin for Latin America, 7, 1-12.

Qureshi, M. S., and Sugawara, N. (2018). Surges and reversals in capital flows. International Review of Economics \& Finance, 56, 92-98.

Reese, W., and Weisbach, M. (2002). Protection of Minority Shareholder Interests, Cross-Listing in the United States, and Subsequent Equity Offerings. Journal of Financial Economics, 66(1), 65104.

Roodman, D. M. (2009). A note on the theme of too many instruments, Oxford Bulletin of Economic and Statistics, 71(1), 135-158. 
Rudra, N. (2005). Globalization and the Strengthening of Democracy in the Developing World, American Journal of Political Science, 49(4), 704-30.

Quinn, D.P., and Inclan, C. (1997). The Origins of Financial Openness: A Study of Current and Capital Account Liberalization. American Journal of Political Science, 41(3), 771-813.

Sahay, R., Čihák, M., N’Diaye, P., Barajas, A., Bi, R., Ayala, D., Gao, Y., Kyobe, A., Nguyen, L., Saborowski, C., Svirydzenka, K., and Yousefi, S.R. (2015). Rethinking Financial Deepening: Stability and Growth in Emerging Markets. IMF Staff Discussion Note, SDN/15/08, International Monetary Fund, Washington, D.C.

Saint-Paul, G. (1992). Technological choice, financial markets and economic development. European Economic Review, 36(4), 763-781.

Schmukler, S. and Vesperoni, E. (2006). Financial Globalization and Debt Maturity in Emerging Economies. Journal of Development Economics, 79(1), 183-207.

Shikimi, M., and Yamada, K. (2019). Trade and financial channels as the transmission mechanism of the financial crisis. International Review of Economics \& Finance, 63, 364-381.

Singh, A. (2003). Capital Account Liberalization, Free Long-Term Capital Flows, Financial Crises and Economic Development. Eastern Economic Journal, 29(2), 191-216.

Singer, H. (1950). The distribution of gains between investing and borrowing countries. American Economic Review, Papers and Proceedings of the Sixty-second Annual Meeting of the American Economic Asociation (May, 1950), 40(2), 473-485.

Sorensen, B.E., Wu, Y.T., Yosha, O., and Zhu, Y. (2007). Home bias and international risk sharing: twin puzzles separated at birth. Journal of International Money and Finance, 26(4), 587-605.

Squalli, J., and Wilson, K. (2011). A New Measure of Trade Openness. The World Economy, 34(10), 1745-1770.

Stanley, D. L., and Bunnag, S. (2001). A new look at the benefits of diversification: lessons from Central America. Applied Economics, 33, 1369-83.

Steinberg, D.A., Nelson, S.C., and Nguyen, C. (2018). Does democracy promote capital account liberalization? Review of International Political Economy, 25(6), 854-883.

Stojkoski, V., Utkovski, Z., and Kocarev, L. (2016). The Impact of Services on Economic Complexity: Service Sophistication as Route for Economic Growth. PLoS ONE, 11(8), e0161633.

Strobl, E. (2005). 'Export Diversification and Price Uncertainty in Developing Countries: A Portfolio Theory Approach. Paper presented at the UNU-WIDER Conference 'The Future of Development Economics'. Helsinki, Finland, 18 June 2005.

Stulz, R. (1999). Globalization, Corporate Finance and the Cost of Capital. Journal of Applied Corporate Finance, 12(3), 8-25.

Stulz, R. (2005). The Limits of Financial Globalization. Journal of Finance, 60(4), 1595-1638. 
Summers, L.H. (2000). International financial crises: causes, prevention, and cures. American Economic Review, 90 (2), 1-16.

Sun, F. (2014). The dual political effects of foreign direct investment in developing countries. The Journal of Developing Areas, 48(1), 107-125.

Swamy, V., and Narayanamurthy, V. (2017). What drives the capital flows into BRICS economies? The World Economy, 41(2), 519-549.

Tokunaga, M., and Iwasaki, I. (2017). The Determinants of Foreign Direct Investment in Transition Economies: A Meta-analysis. The World Economy, 40(12), 2771-2831.

Tornell, A., Westermann, F., and Martinez, L. (2004). The positive link between financial liberalization growth and crises. NBER working paper no. 10293. Cambridge, MA.

Turk Ariss, R. (2016). Legal Systems, Capital Structure, and Debt Maturity in Developing Countries. Corporate Governance, 24(2), 130-144.

Tytell, I., and Wei, S-J. (2004). Does Financial Globalization Induce Better Macroeconomic Policies? IMF Working Paper 04/84. International Monetary Fund, Washington, D.C.

Van Der Marel, E. (2012). Determinants of comparative advantage in services. Working paper no. 87. Vienna: FIW.

Vannoorenberghe, G., Wang, Z., and Yu, Z. (2016). Volatility and diversification of exports: Firmlevel theory and evidence. European Economic Review, 89, 216-247.

Vo, X. V., and Daly, K. J. (2007). The determinants of international financial integration. Global Finance Journal, 18(2), 228-250.

Von Furstenberg, G.M. (1998). From worldwide capital mobility to international financial integration: A Review Essay. Open Economies Review, 9, 53-89.

Wei, S-J. (2000). How taxing is corruption on international investors? Review of Economics and Statistics, 82 (1), 1-11.

Wei, S.J. (2018). Managing financial globalization: insights from the Recent Literature, NBER working paper, No. 24330, Cambridge, MA.

World Trade Organization (WTO). (2019). Market access for products and services of export interest to least developed countries. Note by the secretariat WT/COMTD/LDC/W/67 for the Sub-Committee on Least Developed Countries, 15 October 2019. WTO, Geneva, Switzerland.

Zhuang, H. (2017). The effect of foreign direct investment on human capital development in East Asia. Journal of the Asia Pacific Economy, 22(2), 195-211. 


\section{FIGURES}

Figure 1: Export concentration and financial openness_Over the full sample and the sub-sample of HICs

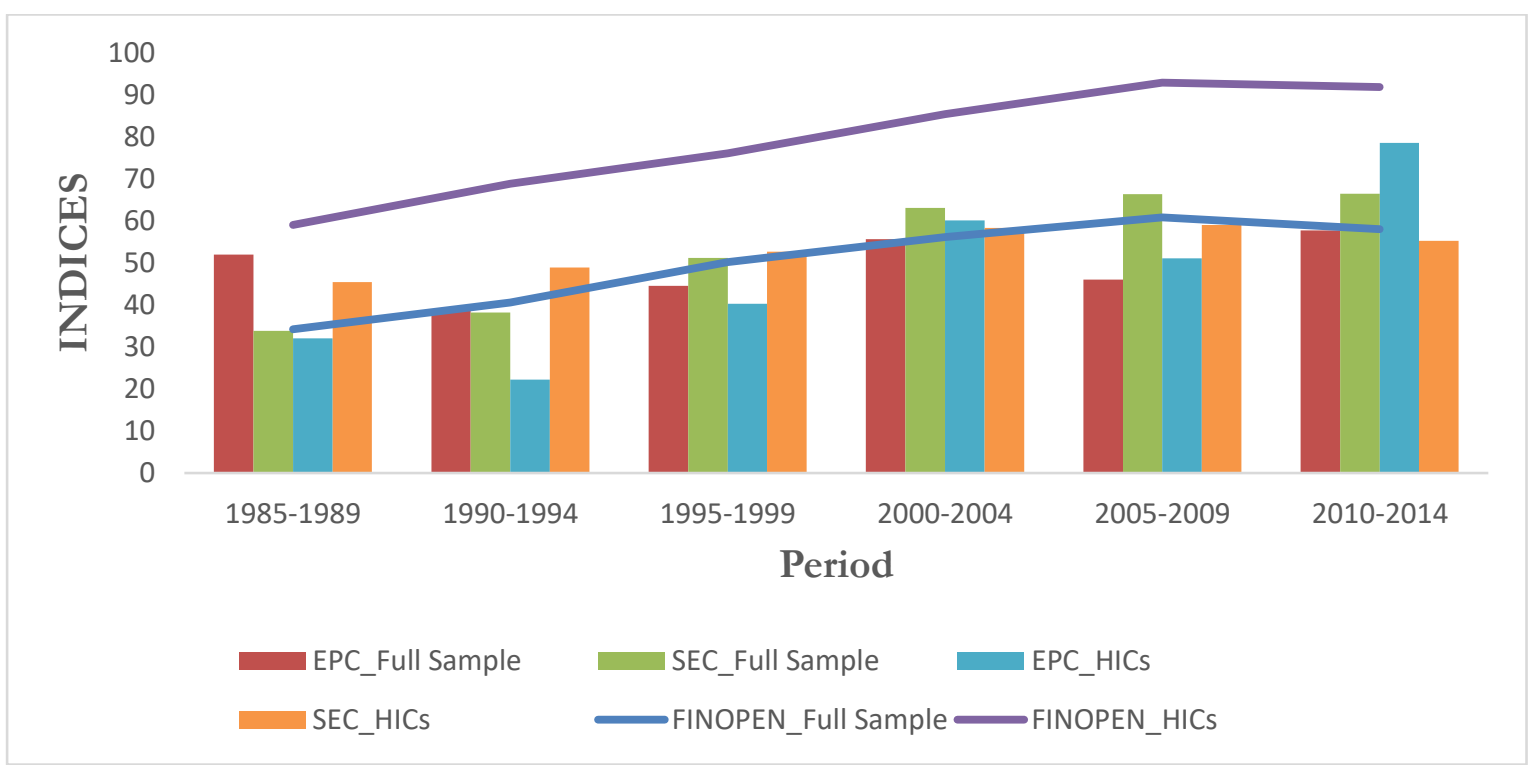

Source: Author

Figure 2: Export concentration and financial openness_Over the sub-samples of NonHICs and LDCs

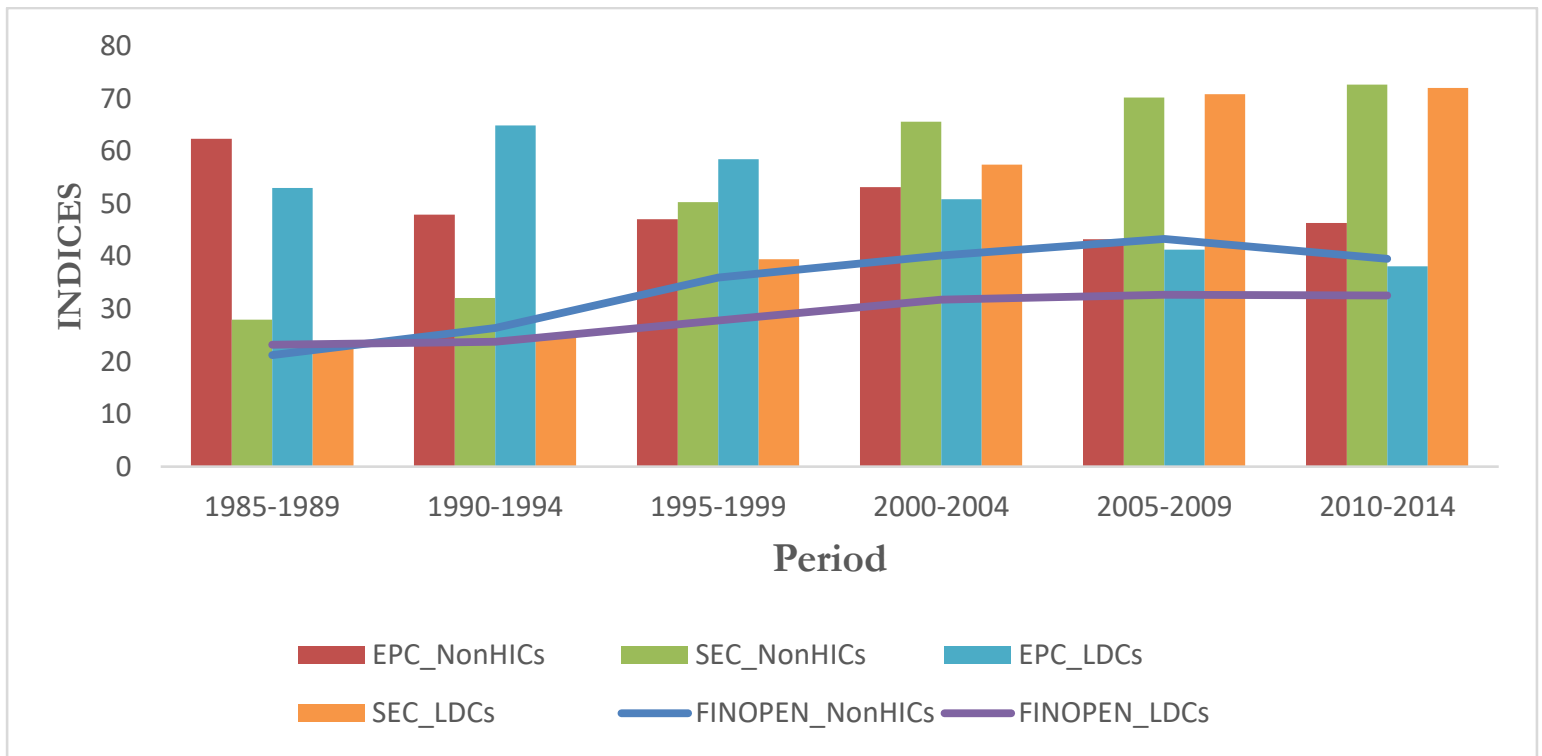

Source: Author 
Figure 3: Correlation pattern between export concentration and financial openness_Over the full sample
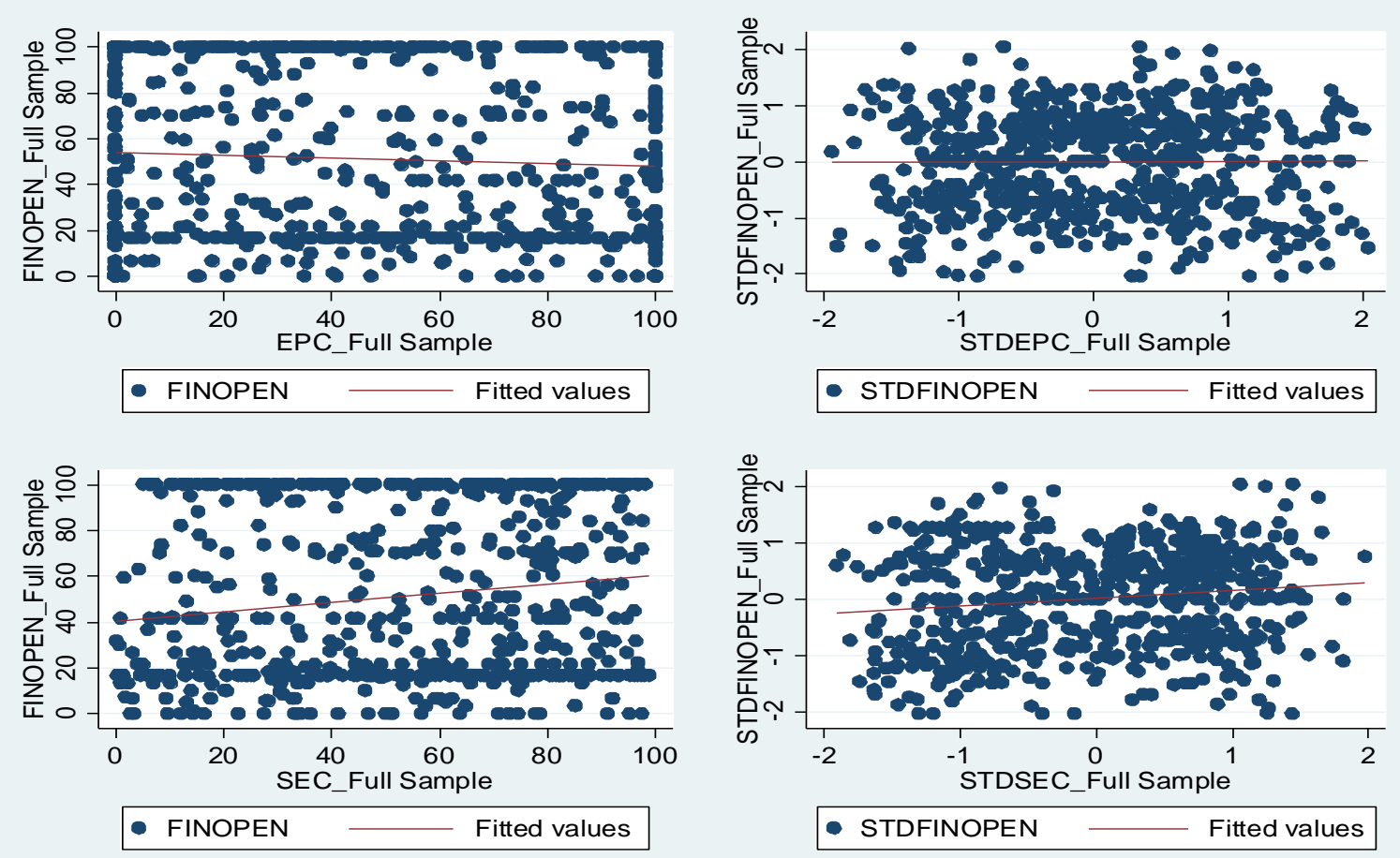

Source: Author

Figure 4: Correlation pattern between export concentration and financial openness_Over the subsample of HICs
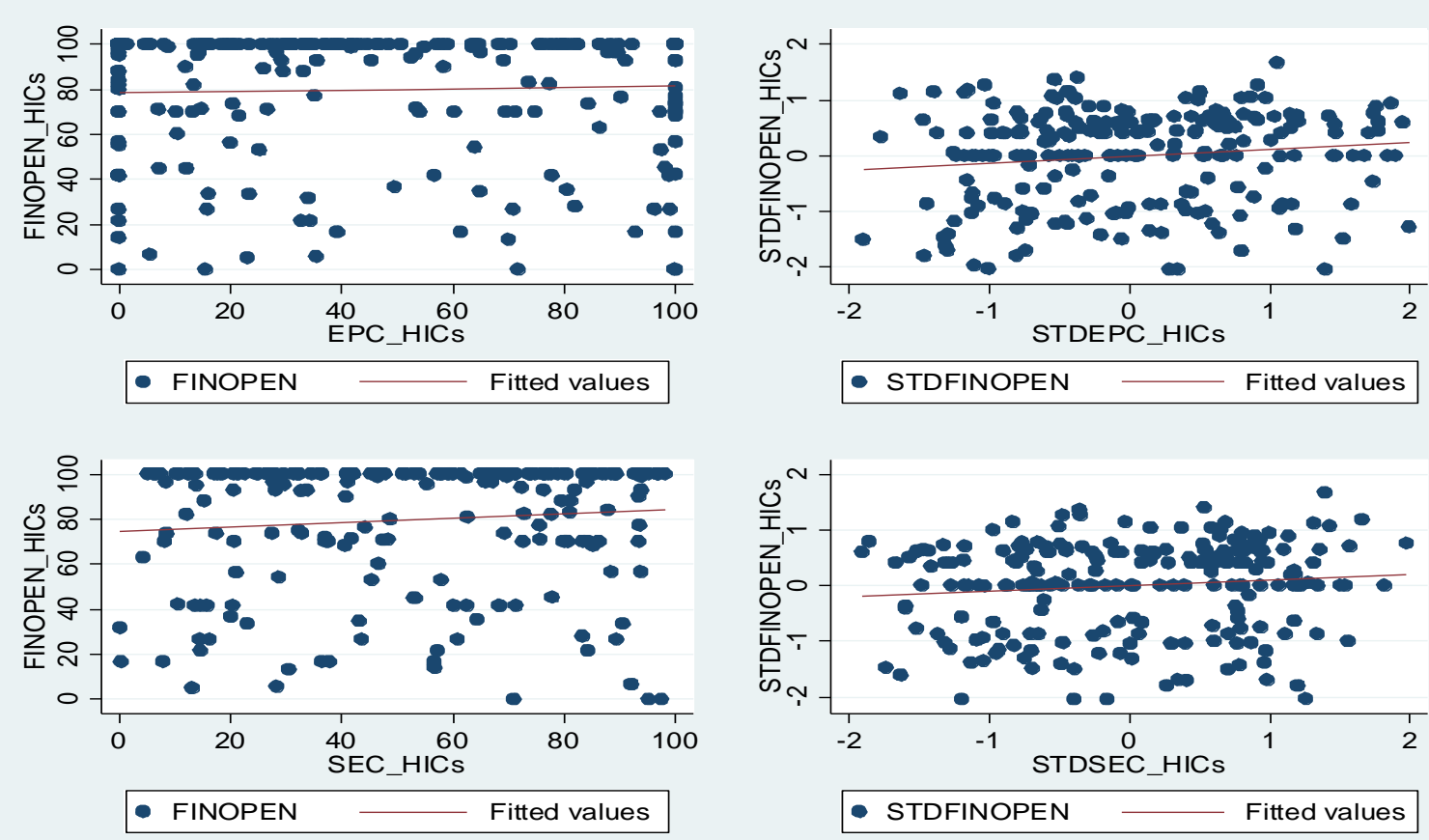

Source: Author 
Figure 5: Correlation pattern between export concentration and financial openness_Over the subsample of NonHICs
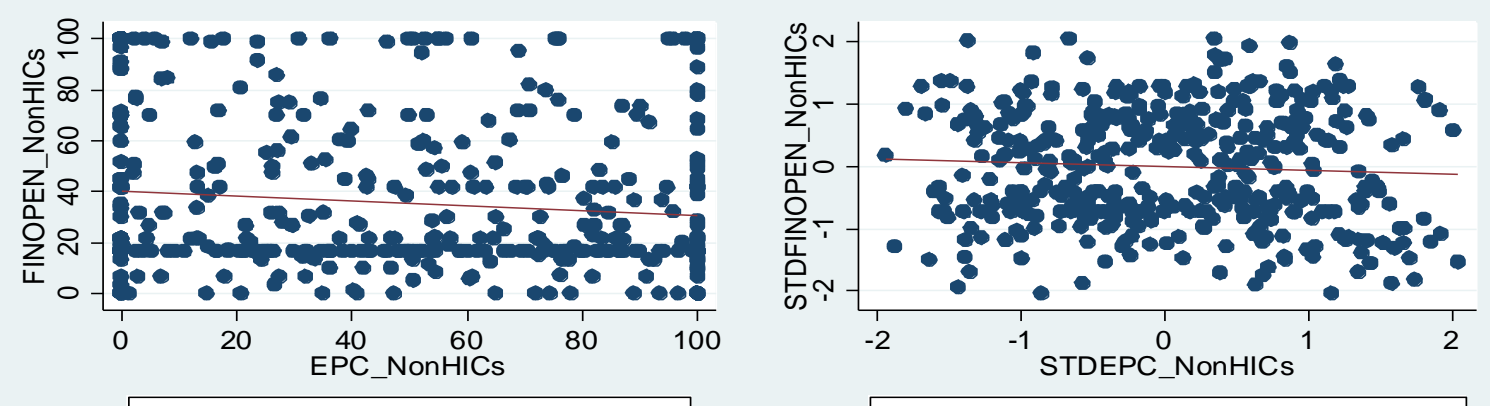

- FINOPEN — Fitted values
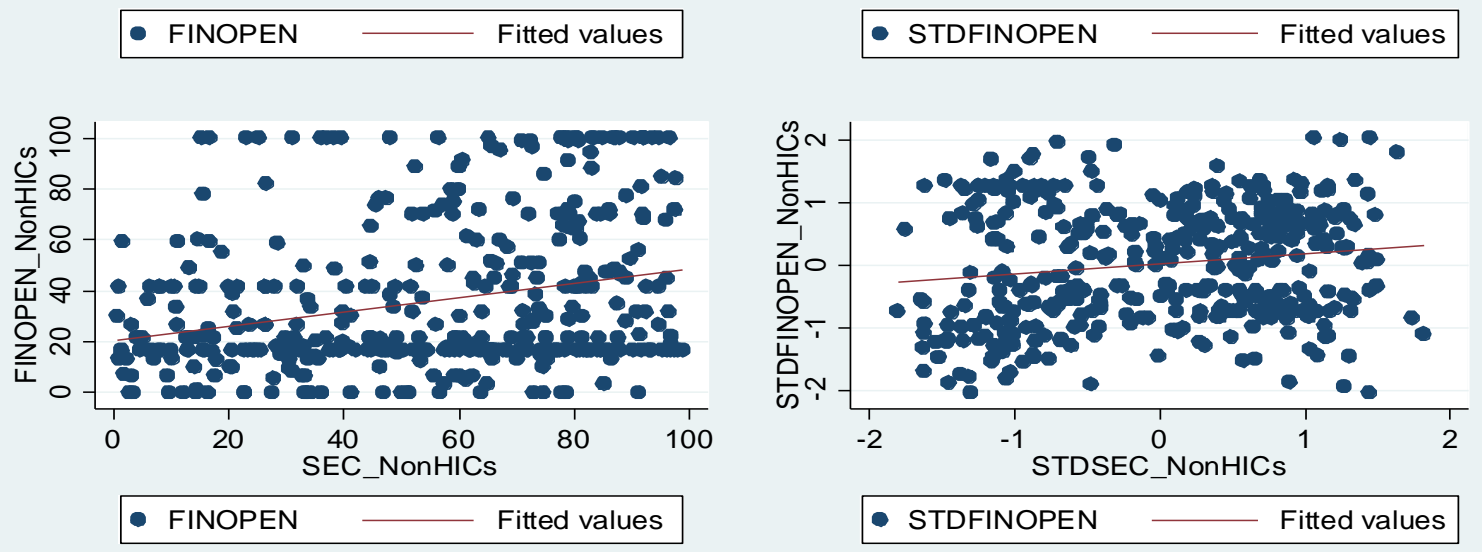

- STDFINOPEN — Fitted values

Source: Author

Figure 6: Correlation pattern between export concentration and financial openness_Over the subsample of LDCs
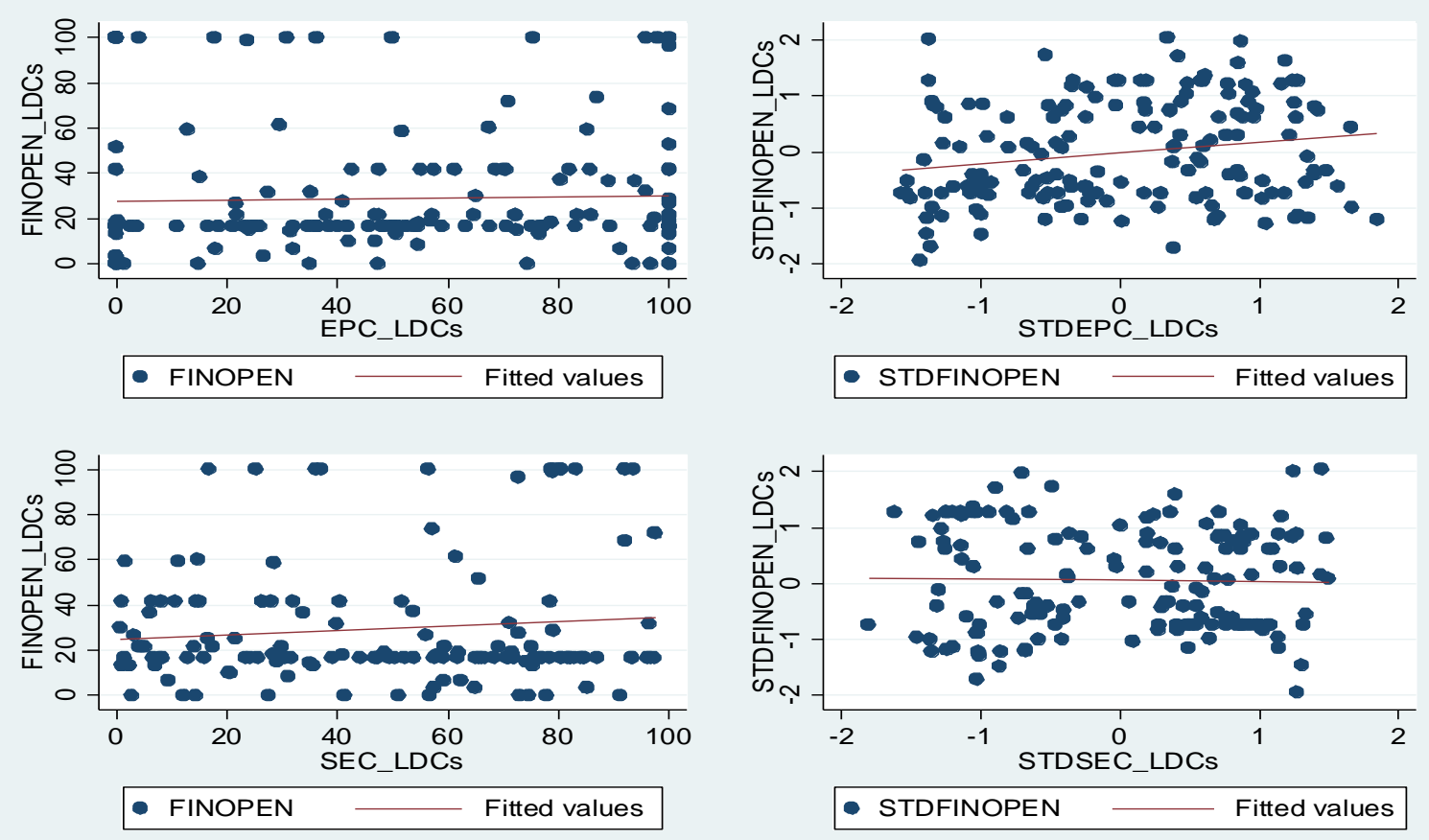

Source: Author 


\section{TABLES and APPENDICES}

Table 1: Effect of export diversification on financial openness

Estimator: Two-Step System GMM

\begin{tabular}{|c|c|c|c|c|}
\hline Variables & FINOPEN & FINOPEN & FINOPEN & FINOPEN \\
\hline & $(1)$ & (2) & (3) & (4) \\
\hline \multirow[t]{2}{*}{ FINOPEN $_{\mathrm{t}-1}$} & $0.546^{* * *}$ & $0.532^{* * *}$ & $0.519^{* * *}$ & $0.559 * * *$ \\
\hline & $(0.0158)$ & $(0.0157)$ & $(0.0141)$ & $(0.0153)$ \\
\hline \multirow[t]{2}{*}{ EPC } & $-0.136 * * *$ & $-0.247 * * *$ & $-0.175^{* * *}$ & $-0.170 * * *$ \\
\hline & $(0.0252)$ & $(0.0393)$ & $(0.0277)$ & $(0.0345)$ \\
\hline \multirow[t]{2}{*}{ SEC } & $-0.0748^{* * *}$ & $-0.136^{* * *}$ & -0.0360 & $-0.0798 * * *$ \\
\hline & $(0.0258)$ & $(0.0430)$ & $(0.0234)$ & $(0.0293)$ \\
\hline \multirow[t]{2}{*}{ EPC*HIC } & & $0.330 * * *$ & & \\
\hline & & $(0.0454)$ & & \\
\hline \multirow[t]{2}{*}{ SEC*HIC } & & $0.236 * * *$ & & \\
\hline & & $(0.0618)$ & & \\
\hline \multirow[t]{2}{*}{ EPC*LDC } & & & $0.157^{* * *}$ & \\
\hline & & & $(0.0556)$ & \\
\hline \multirow[t]{2}{*}{ SEC*LDC } & & & -0.0292 & \\
\hline & & & $(0.0432)$ & \\
\hline \multirow[t]{2}{*}{ EPC*GDPC } & & & & $0.0940^{* * *}$ \\
\hline & & & & $(0.0254)$ \\
\hline \multirow[t]{2}{*}{ SEC*GDPC } & & & & $0.0648^{* * *}$ \\
\hline & & & & $(0.0236)$ \\
\hline \multirow[t]{2}{*}{$\mathrm{HIC}$} & & $0.388^{* * *}$ & & \\
\hline & & $(0.0590)$ & & \\
\hline \multirow[t]{2}{*}{ LDC } & & & $-0.232 * * *$ & \\
\hline & & & $(0.0612)$ & \\
\hline \multirow[t]{2}{*}{ GDPC } & $-0.0772^{* *}$ & $-0.0766^{* *}$ & $-0.0706^{* *}$ & $-0.140 * * *$ \\
\hline & $(0.0365)$ & $(0.0382)$ & $(0.0344)$ & $(0.0377)$ \\
\hline \multirow[t]{2}{*}{ OPEN } & 0.0188 & $0.0784 * * *$ & $0.0493^{* *}$ & 0.0238 \\
\hline & $(0.0245)$ & $(0.0267)$ & $(0.0234)$ & $(0.0249)$ \\
\hline \multirow[t]{2}{*}{ DEM } & $-0.114^{* *}$ & -0.0270 & $-0.0939 * *$ & $-0.0909^{*}$ \\
\hline & $(0.0460)$ & $(0.0439)$ & $(0.0457)$ & $(0.0476)$ \\
\hline \multirow[t]{2}{*}{ HUM } & $-0.115^{* *}$ & $-0.0742^{*}$ & $-0.115^{* * *}$ & $-0.107 * *$ \\
\hline & $(0.0467)$ & $(0.0443)$ & $(0.0416)$ & $(0.0442)$ \\
\hline \multirow[t]{2}{*}{ INFL } & $-0.286^{* * *}$ & $-0.230 * * *$ & $-0.253 * * *$ & $-0.279 * * *$ \\
\hline & $(0.0368)$ & $(0.0342)$ & $(0.0395)$ & $(0.0331)$ \\
\hline \multirow[t]{2}{*}{ FINDEV } & $0.168^{* * *}$ & 0.0520 & $0.159 * * *$ & $0.210^{* * *}$ \\
\hline & $(0.0356)$ & $(0.0448)$ & $(0.0319)$ & $(0.0385)$ \\
\hline \multirow[t]{2}{*}{ POP } & $-0.178 * * *$ & $-0.169 * * *$ & $-0.174 * * *$ & $-0.158 * * *$ \\
\hline & $(0.0340)$ & $(0.0343)$ & $(0.0277)$ & $(0.0358)$ \\
\hline Observations - Countries & $515-119$ & $515-119$ & $515-119$ & $515-119$ \\
\hline Number of Instruments & 91 & 95 & 95 & 93 \\
\hline AR1 (P-Value) & 0.0001 & 0.0001 & 0.0001 & 0.0001 \\
\hline AR2 (P-Value) & 0.8141 & 0.9357 & 0.7515 & 0.8806 \\
\hline
\end{tabular}




\begin{tabular}{|c|c|c|c|c|}
\hline AR3 (P-Value) & 0.2064 & 0.1372 & 0.2502 & 0.2105 \\
\hline OID (P-Value) & 0.1804 & 0.1853 & 0.2474 & 0.2540 \\
\hline
\end{tabular}

Note: ${ }^{*}$-value $<0,1 ;{ }^{* *}$-value $<0,05 ;{ }^{* *}$ p-value $<0,01$. Robust Standard errors are in parenthesis. All variables used in the regressions have been standardized. The variables "EPC", "SEC", "FINDEV", "INFL", "OPEN", "DEM" and "HUM" bave been considered as endogenous. 
Table 2: Channels through which export diversification affects financial openness Estimator: Two-Step System GMM

\begin{tabular}{|c|c|c|c|}
\hline Variables & FINOPEN & FINOPEN & FINOPEN \\
\hline & (1) & $(2)$ & (3) \\
\hline \multirow[t]{2}{*}{ FINOPEN $_{\mathrm{t}-1}$} & $0.517 * * *$ & $0.517 * * *$ & $0.548^{* * *}$ \\
\hline & $(0.0201)$ & $(0.0144)$ & $(0.0165)$ \\
\hline \multirow{2}{*}{ EPC } & $-0.211 * * *$ & $-0.0778^{* * *}$ & $-0.104 * * *$ \\
\hline & $(0.0311)$ & $(0.0235)$ & $(0.0278)$ \\
\hline \multirow[t]{2}{*}{ SEC } & 0.00129 & $-0.102^{* * *}$ & $-0.103 * * *$ \\
\hline & $(0.0286)$ & $(0.0347)$ & $(0.0358)$ \\
\hline \multirow[t]{2}{*}{ EPC*SHOCK } & $-0.257 * * *$ & & \\
\hline & $(0.0520)$ & & \\
\hline \multirow{2}{*}{ SEC*SHOCK } & $0.184^{* * *}$ & & \\
\hline & $(0.0433)$ & & \\
\hline \multirow[t]{2}{*}{ EPC*GRVOL } & & $-0.132^{* * *}$ & \\
\hline & & $(0.0396)$ & \\
\hline \multirow[t]{2}{*}{ SEC*GRVOL } & & $0.0624^{* *}$ & \\
\hline & & $(0.0295)$ & \\
\hline \multirow{2}{*}{ EPC*GROWTH } & & & $-0.0860 * *$ \\
\hline & & & $(0.0416)$ \\
\hline \multirow[t]{2}{*}{ SEC*GROWTH } & & & $-0.123 * * *$ \\
\hline & & & $(0.0383)$ \\
\hline \multirow[t]{2}{*}{ SHOCK } & $-0.152^{* * *}$ & & \\
\hline & $(0.0273)$ & & \\
\hline \multirow[t]{2}{*}{ GRVOL } & & $0.117 * * *$ & \\
\hline & & $(0.0224)$ & \\
\hline \multirow[t]{2}{*}{ GROWTH } & & & $0.152^{* * *}$ \\
\hline & & & $(0.0309)$ \\
\hline \multirow[t]{2}{*}{ GDPC } & $-0.186^{* * *}$ & $-0.0888^{* * *}$ & -0.0610 \\
\hline & $(0.0441)$ & $(0.0328)$ & $(0.0399)$ \\
\hline \multirow[t]{2}{*}{ OPEN } & -0.0299 & 0.0426 & $0.0744^{* *}$ \\
\hline & $(0.0318)$ & $(0.0295)$ & $(0.0362)$ \\
\hline \multirow[t]{2}{*}{ DEM } & $0.0826^{*}$ & $-0.113^{* * *}$ & $-0.142^{* * *}$ \\
\hline & $(0.0448)$ & $(0.0426)$ & $(0.0472)$ \\
\hline \multirow[t]{2}{*}{ HUM } & -0.0450 & -0.0476 & $-0.116^{* * *}$ \\
\hline & $(0.0519)$ & $(0.0362)$ & $(0.0415)$ \\
\hline \multirow[t]{2}{*}{ INFL } & $-0.150 * * *$ & $-0.366^{* * *}$ & $-0.245^{* * *}$ \\
\hline & $(0.0371)$ & $(0.0256)$ & $(0.0375)$ \\
\hline \multirow[t]{2}{*}{ FINDEV } & $0.240^{* * *}$ & 0.0781 & $0.149 * * *$ \\
\hline & $(0.0379)$ & $(0.0475)$ & $(0.0467)$ \\
\hline \multirow[t]{2}{*}{ POP } & $-0.164^{* * *}$ & $-0.184^{* * *}$ & $-0.140 * * *$ \\
\hline & $(0.0381)$ & $(0.0303)$ & $(0.0278)$ \\
\hline Observations - Countries & $447-111$ & $515-119$ & $515-119$ \\
\hline Number of Instruments & 94 & 96 & 96 \\
\hline AR1 (P-Value) & 0.0003 & 0.0001 & 0.0001 \\
\hline AR2 (P-Value) & 0.9045 & 0.9313 & 0.7756 \\
\hline
\end{tabular}




\begin{tabular}{|c|c|c|c|}
\hline AR3 (P-Value) & 0.5809 & 0.3946 & 0.10 \\
\hline OID (P-Value) & 0.2161 & 0.5595 & 0.1949 \\
\hline
\end{tabular}

Note: ${ }^{*}$-value $<0,1 ;{ }^{*}$ p-value $<0,05 ;{ }^{* *}$ p-value $<0,01$. Robust Standard errors are in parenthesis. All variables used in the regressions have been standardized. The variables "EPC", "SEC", "GROWTH", "SHOCK", "GRVOL", "FINDEV", "INFL", "OPEN", "DEM" and "HUM" bave been considered as endogenous. 
Table 3: Interaction effect between the effect of export product concentration and services export concentration on financial openness in the context of greater external shocks

Estimator: Two-Step System GMM

\begin{tabular}{|c|c|c|}
\hline Variables & FINOPEN & FINOPEN \\
\hline & $(1)$ & (2) \\
\hline \multirow[t]{2}{*}{ FINOPEN $_{\mathrm{t}-1}$} & $0.525^{* * *}$ & $0.515^{* * *}$ \\
\hline & $(0.0221)$ & $(0.0144)$ \\
\hline \multirow[t]{2}{*}{ EPC } & $-0.116^{* *}$ & $-0.0694 * *$ \\
\hline & $(0.0449)$ & $(0.0271)$ \\
\hline \multirow[t]{2}{*}{ SEC } & -0.0592 & $0.0495^{*}$ \\
\hline & $(0.0399)$ & $(0.0268)$ \\
\hline \multirow[t]{2}{*}{ EPC*SEC } & $-0.204 * * *$ & $-0.237 * * *$ \\
\hline & $(0.0563)$ & $(0.0361)$ \\
\hline \multirow{2}{*}{ EPC*SEC*SHOCK } & & $-0.111 * * *$ \\
\hline & & $(0.0310)$ \\
\hline \multirow[t]{2}{*}{ EPC*SHOCK } & & $-0.133^{* * *}$ \\
\hline & & $(0.0211)$ \\
\hline \multirow[t]{2}{*}{ SEC*SHOCK } & & $0.0583 * * *$ \\
\hline & & $(0.0226)$ \\
\hline \multirow[t]{2}{*}{ SHOCK } & & $-0.101 * * *$ \\
\hline & & $(0.0167)$ \\
\hline \multirow[t]{2}{*}{ GDPC } & $-0.169 * * *$ & $-0.209 * * *$ \\
\hline & $(0.0487)$ & $(0.0224)$ \\
\hline \multirow[t]{2}{*}{ OPEN } & 0.0574 & 0.0125 \\
\hline & $(0.0477)$ & $(0.0283)$ \\
\hline \multirow[t]{2}{*}{ DEM } & -0.0502 & $-0.0624 * *$ \\
\hline & $(0.0560)$ & $(0.0280)$ \\
\hline \multirow[t]{2}{*}{ HUM } & $-0.153 * * *$ & $0.0639 * *$ \\
\hline & $(0.0578)$ & $(0.0269)$ \\
\hline \multirow[t]{2}{*}{ INFL } & $-0.319 * * *$ & $-0.0877 * * *$ \\
\hline & $(0.0404)$ & $(0.0173)$ \\
\hline \multirow[t]{2}{*}{ FINDEV } & $0.254 * * *$ & $0.185^{* * *}$ \\
\hline & $(0.0656)$ & $(0.0288)$ \\
\hline \multirow[t]{2}{*}{ POP } & $-0.160^{* * *}$ & $-0.205^{* * *}$ \\
\hline & $(0.0364)$ & $(0.0193)$ \\
\hline \multirow[t]{2}{*}{ Constant } & $0.232^{* * *}$ & $0.202^{* * *}$ \\
\hline & $(0.0139)$ & $(0.0121)$ \\
\hline Observations - Countries & $515-119$ & $447-111$ \\
\hline Number of Instruments & 80 & 106 \\
\hline AR1 (P-Value) & 0.0001 & 0.0003 \\
\hline AR2 (P-Value) & 0.9658 & 0.9697 \\
\hline AR3 (P-Value) & 0.3745 & 0.4913 \\
\hline OID (P-Value) & 0.1426 & 0.4828 \\
\hline
\end{tabular}

Note: ${ }^{*}$-value $<0,1 ;{ }^{* *}$-value $<0,05 ;{ }^{* *}$-v-value $<0,01$. Robust Standard errors are in parenthesis. All variables used in the regressions have been standardized. The variables "EPC", "SEC", "SHOCK", "FINDEV", "INFL", "OPEN", "DEM" and "HUM" bave been considered as endogenous. 
Appendix 1: Definition and Source of variables

\begin{tabular}{|c|c|c|}
\hline Variables & Definition & Sources \\
\hline FINOPEN & This is the measure of financial policy, i.e., de jure financial openness. & $\begin{array}{l}\text { This index has been computed by Chinn and Ito (2006) and } \\
\text { updated in July } 2020 \text {. Its value ranges between } 0 \text { and } 1 \text {. See: } \\
\text { http://web.pdx.edu/ ito/Chinn-Ito website.htm } \\
\text { For the purpose of the present study, we have transformed this } \\
\text { index by multiplying its values by } 100 \text {. So, its values range here } \\
\text { between } 0 \text { and } 100 \text {. }\end{array}$ \\
\hline EPC & $\begin{array}{l}\text { This is the variable capturing overall export product concentration. It is } \\
\text { calculated using the Theil Index and following the definitions and } \\
\text { methods used in Cadot et al. (2011). The overall Theil index of export } \\
\text { product concentration is the sum of the intensive and extensive } \\
\text { components. In fact, export product diversification can occur either } \\
\text { over product narrowly defined or trading partners. It can be broken } \\
\text { down into the extensive and intensive margins of diversification. } \\
\text { Extensive export diversification reflects an increase in the number of } \\
\text { export products or trading partners, while intensive export } \\
\text { diversification considers the shares of export volumes across active } \\
\text { products or trading partners. The computation of the index has been } \\
\text { based on a classification of products into "Traditional", "New", or } \\
\text { "Non-Traded" products categories. A rise in the values of "ECI" index } \\
\text { signifies an increase in the degree of overall export product } \\
\text { concentration, while a decrease in the values of the index reflects a rise } \\
\text { in the degree of overall export product concentration (that is, greater } \\
\text { export product diversification). }\end{array}$ & $\begin{array}{l}\text { Details on the calculation of this Index could be found online: } \\
\text { International Monetary Fund's Diversification Toolkit - See data } \\
\text { online at: https://data.imf.org/?sk=3567E911-4282-4427-98F9- } \\
\text { 2B8A6F83C3B6 }\end{array}$ \\
\hline SEC & $\begin{array}{l}\text { This variable represents the Theil index of services export concentration. } \\
\text { It has been calculated using the following formula (for example, see } \\
\text { Agosin et al, 2011; Cadot et al., 2011): THEIL }=\frac{1}{n} \sum_{k=1}^{n} \frac{x_{k}}{\mu} \ln \left(\frac{x_{k}}{\mu}\right) \\
\text { where } \mu=\frac{1}{n} \sum_{k=1}^{n} x_{k} \\
\text { n represents the total number of the (services) export lines (k) } n= \\
\qquad \sum_{k=1}^{n} k\end{array}$ & $\begin{array}{l}\text { Author's calculation based on data extracted from the database } \\
\text { developed by the International Monetary Fund (IMF) on the } \\
\text { international trade in services (see online at: } \\
\text { https://data.imf.org/?sk=07109577-E65D-4CE1-BB21- } \\
\text { 0CB3098FC504) - See also Loungani et al. (2017). The data used } \\
\text { to compute the HHI indicator are sectoral data on services } \\
\text { exports at 2-digit level, which is the maximum digit-level of }\end{array}$ \\
\hline
\end{tabular}




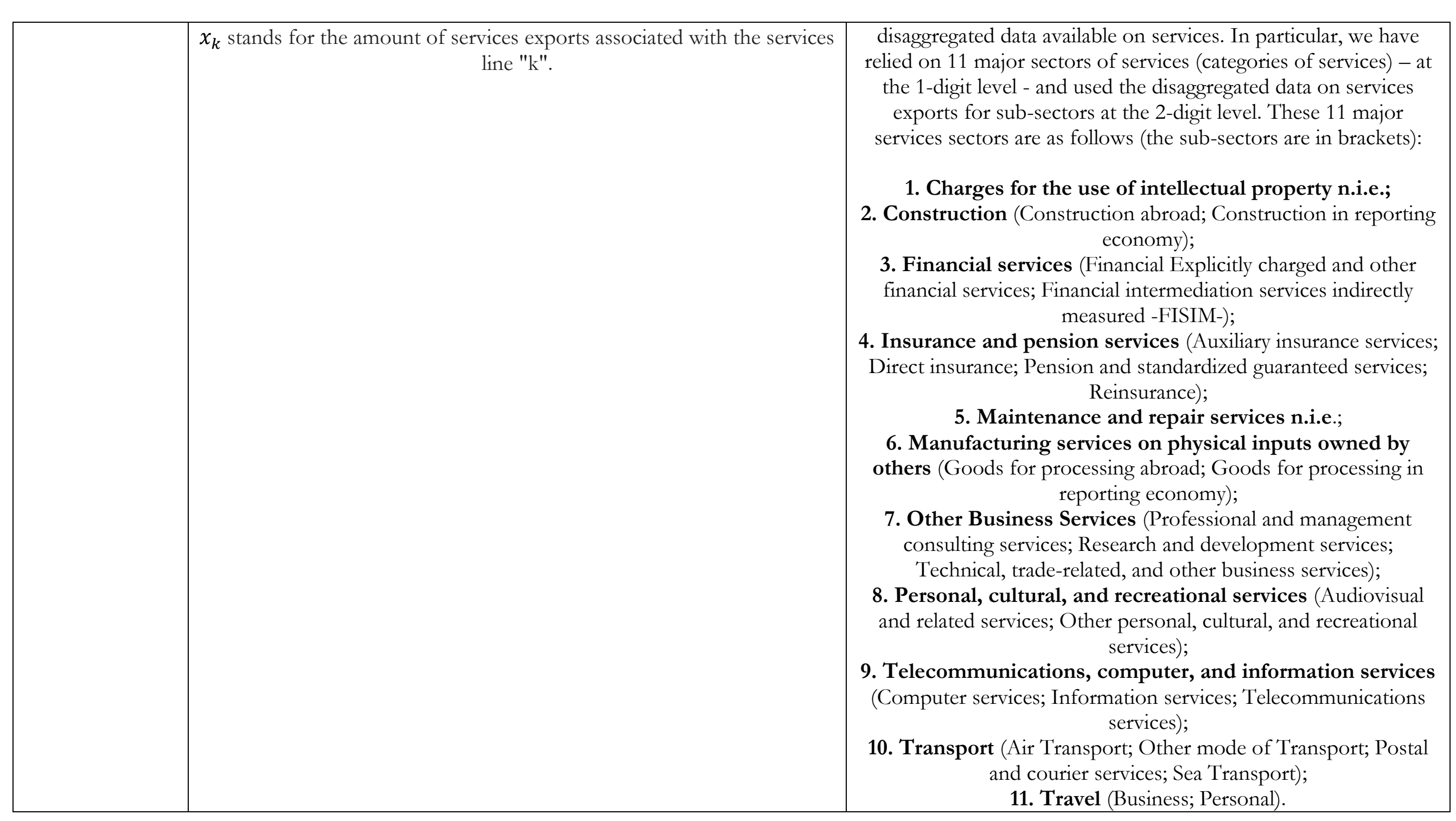




\begin{tabular}{|c|c|c|}
\hline FINDEV & $\begin{array}{l}\text { This is another the financial development index (computed by the } \\
\text { International Monetary Fund), which summarizes how developed } \\
\text { financial institutions and financial markets are in terms of their depth } \\
\text { (size and liquidity), access (ability of individuals and companies to access } \\
\text { financial services), and efficiency (ability of institutions to provide } \\
\text { financial services at low costs and with sustainable revenues, and the } \\
\text { level of activity of capital markets). }\end{array}$ & $\begin{array}{l}\text { Data extracted from the IMF Financial Development Index } \\
\text { Database (see online at: } \underline{\text { https://data.imf.org/?sk=F8032E80- }} \\
\underline{\text { B36C-43B1-AC26-493C5B1CD33B }) \text { - See also Sahay et al. (2015). }}\end{array}$ \\
\hline GDPC & GDP per capita (constant 2010 US\$) & WDI \\
\hline HUM & $\begin{array}{l}\text { Human capital index, based on years of schooling and returns to } \\
\text { education. }\end{array}$ & Penn World Tables, version 9.1 (see Feenstra et al., 2015). \\
\hline SHOCK & $\begin{array}{l}\text { This the shock variable, which represents the exchange rate pressure. } \\
\qquad \text { It has been computed as follows: } \\
\qquad \operatorname{SHOCK}_{\mathrm{it}}=w_{E, i} \frac{\Delta E_{i t}}{E_{i, t-1}}-w_{R E S, i} \frac{\Delta R E S_{i t}}{R E S_{i, t-1}} \\
\boldsymbol{E} \text { is the exchange rate in local currency units per USD; } \boldsymbol{R E S} \text { is the size of } \\
\text { reserves, } w_{E, i} \text { and } w_{R E S, i} \text { are country-specific weights: } w_{E, i}=\frac{\sigma_{R E S, i}}{\sigma_{R E S, i}+\sigma_{E, i}} \\
\text { and } w_{R E S, i}=\frac{\sigma_{E, i}}{\sigma_{R E S, i}+\sigma_{E, i}} \cdot \sigma_{R E S, i} \text { stands for the standard deviation of } \\
\frac{\Delta R E S_{i t}}{R E S_{i, t-1}} \text { over the full period of the analysis (here, 1980-2014). Similarly, } \\
\sigma_{E, i} \text { is the standard deviation of } \frac{\Delta E_{i t}}{E_{i, t-1}} \text { over the full period of the analysis } \\
\text { (here, 1980-2014). The indicator "SHOCK" has been computed using the } \\
\text { annual data over the period 1980-2014. }\end{array}$ & Author's calculation based on data from the WDI. \\
\hline GRVOL & $\begin{array}{l}\text { This is the measure of the volatility of economic growth rate. It has been } \\
\text { calculated as the standard deviation of annual economic growth rate } \\
\text { (growth rate of real GDP) over non-overlapping sub-periods of 5-year. }\end{array}$ & $\begin{array}{c}\text { Authors' calculation based on economic growth rate data } \\
\text { extracted from the WDI }\end{array}$ \\
\hline GROWTH & Annual GDP growth $(\%)$ & Data extracted from the WDI. \\
\hline INFL & $\begin{array}{l}\text { The annual inflation rate }(\%) \text { is based on Consumer Price Index -CPI- } \\
\text { (annual \%) where missing values has been replaced with values of the } \\
\text { GDP Deflator (annual \%). }\end{array}$ & Authors' calculation based on data from the WDI. \\
\hline OPEN & $\begin{array}{l}\text { This is the measure of (de facto) trade openness proposed by Squalli and } \\
\text { Wilson (2011). It is calculated as the measure of the share of sum of }\end{array}$ & Author's calculation based on data from the WDI \\
\hline
\end{tabular}




\begin{tabular}{|c|c|c|}
\hline POP & $\begin{array}{c}\text { exports and imports of goods and services in GDP, adjusted by the } \\
\text { proportion of a country's trade level relative to the average world trade } \\
\text { (see Squalli and Wilson, 2011: p1758). }\end{array}$ & Total Population \\
\hline DEM & $\begin{array}{c}\text { This variable is an index extracted from Polity IV Database (Marshall et } \\
\text { al., 2018). It represents the degree of democracy based on } \\
\text { competitiveness of political participation, the openness and } \\
\text { competitiveness of executive recruitment and constraints on the chief } \\
\text { executive. Its values range between -10 and +10, with lower values } \\
\text { reflecting autocratic regimes, and greater values indicating democratic } \\
\text { regimes. Specifically, the value +10 for this index represents a strong } \\
\text { democratic regime, while the value -10 stands for strong autocratic } \\
\text { regime. }\end{array}$ & Polity IV Database (Marshall et al., 2018) \\
\hline
\end{tabular}

.

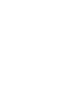


Appendix 2a: Descriptive statistics on unstandardized (non-transformed) variables used in the analysis

\begin{tabular}{|c|c|c|c|c|c|}
\hline Variable & Observations & Mean & Standard deviation & Minimum & Maximum \\
\hline FINOPEN & 515 & 55.019 & 35.683 & 0.000 & 100.000 \\
\hline EPC & 515 & 49.346 & 36.534 & 0.000 & 100.000 \\
\hline SEC & 515 & 58.745 & 26.070 & 0.187 & 98.801 \\
\hline INFL & 515 & 21.121 & 135.137 & -0.521 & 1943.500 \\
\hline OPEN & 515 & 0.006 & 0.012 & 0.000 & 0.089 \\
\hline GROWTH & 515 & 3.857 & 2.654 & -11.480 & 14.988 \\
\hline FINDEV & 515 & 0.325 & 0.230 & 0.036 & 0.935 \\
\hline SHOCK & 447 & 0.240 & 1.649 & -0.200 & 23.433 \\
\hline GRVOL & 515 & 2.696 & 2.287 & 0.244 & 22.239 \\
\hline DEM & 515 & 4.694 & 5.801 & -10.000 & 10.000 \\
\hline HUM & 515 & 2.358 & 0.716 & 1.037 & 3.719 \\
\hline POP & 515 & 42800000 & 130000000 & 522914 & 1350000000 \\
\hline GDPC & 515 & 12557.09 & 16914.26 & 226.3838 & 89835.23 \\
\hline
\end{tabular}

Appendix 2b: Descriptive statistics on standardized variables used in the analysis

\begin{tabular}{|c|c|c|c|c|c|}
\hline Variable & Observations & Mean & Standard deviation & Minimum & Maximum \\
\hline FINOPEN & 515 & 0.145 & 0.783 & -2.041 & 2.041 \\
\hline EPC & 515 & 0.024 & 0.860 & -1.944 & 1.950 \\
\hline SEC & 515 & 0.153 & 0.834 & -1.910 & 1.737 \\
\hline INFL & 515 & -0.176 & 0.790 & -1.755 & 2.016 \\
\hline OPEN & 515 & 0.080 & 0.867 & -1.760 & 1.914 \\
\hline GROWTH & 515 & 0.042 & 0.849 & -1.918 & 1.937 \\
\hline FINDEV & 515 & 0.206 & 0.816 & -1.802 & 1.875 \\
\hline SHOCK & 447 & -0.113 & 0.817 & -1.895 & 2.041 \\
\hline GRVOL & 515 & -0.086 & 0.888 & -1.854 & 2.016 \\
\hline DEM & 515 & 0.208 & 0.612 & -1.965 & 2.037 \\
\hline HUM & 515 & 0.333 & 0.738 & -1.347 & 1.662 \\
\hline POP & 515 & 0.236 & 0.798 & -1.623 & 1.825 \\
\hline GDPC & 515 & 0.205 & 0.837 & -1.762 & 1.871 \\
\hline
\end{tabular}


Appendix 3a: List of countries contained in the full sample

\begin{tabular}{|c|c|c|c|}
\hline \multicolumn{4}{|c|}{ Full sample } \\
\hline Albania & Czech Republic & Lao PDR & Poland \\
\hline Algeria & Denmark & Latvia & Portugal \\
\hline Angola & Dominican Republic & Lesotho & Romania \\
\hline Argentina & Ecuador & Liberia & Russian Federation \\
\hline Armenia & Egypt, Arab Rep. & Lithuania & Rwanda \\
\hline Australia & El Salvador & Madagascar & Saudi Arabia \\
\hline Austria & Estonia & Malawi & Senegal \\
\hline Bahrain & Eswatini & Malaysia & Sierra Leone \\
\hline Bangladesh & Finland & Mali & Singapore \\
\hline Belgium & France & Mauritania & Slovak Republic \\
\hline Benin & Gabon & Mauritius & Slovenia \\
\hline Bolivia & Gambia, The & Mexico & South Africa \\
\hline Botswana & Germany & Moldova & Spain \\
\hline Brazil & Ghana & Mongolia & Sri Lanka \\
\hline Bulgaria & Greece & Morocco & Sudan \\
\hline Burkina Faso & Guatemala & Mozambique & Sweden \\
\hline Burundi & Haiti & Myanmar & Switzerland \\
\hline Cambodia & Honduras & Namibia & Tajikistan \\
\hline Cameroon & Hungary & Nepal & Tanzania \\
\hline Canada & Indonesia & Netherlands & Thailand \\
\hline $\begin{array}{c}\text { Central African } \\
\text { Republic }\end{array}$ & Iran, Islamic Rep. & New Zealand & Tunisia \\
\hline Chile & Ireland & Nicaragua & Turkey \\
\hline China & Israel & Niger & Uganda \\
\hline Colombia & Italy & Nigeria & Ukraine \\
\hline Congo, Dem. Rep. & Japan & Norway & United Kingdom \\
\hline Congo, Rep. & Jordan & Pakistan & United States \\
\hline Costa Rica & Kenya & Panama & Uruguay \\
\hline Cote d'Ivoire & Korea, Rep. & Paraguay & Venezuela, RB \\
\hline Croatia & Kuwait & Peru & Zambia \\
\hline Cyprus & Kyrgyz Republic & Philippines & \\
\hline
\end{tabular}


Appendix 3b: List of countries contained in the sub-samples

\begin{tabular}{|c|c|c|}
\hline \multicolumn{2}{|c|}{ HICs } & LDCs \\
\hline Australia & Panama & Angola \\
\hline Austria & Poland & Bangladesh \\
\hline Bahrain & Portugal & Benin \\
\hline Belgium & Romania & Burkina Faso \\
\hline Canada & Saudi Arabia & Burundi \\
\hline Chile & Singapore & Cambodia \\
\hline Croatia & Slovak Republic & Central African Republic \\
\hline Cyprus & Slovenia & Congo, Dem. Rep. \\
\hline Czech Republic & Spain & Gambia, The \\
\hline Denmark & Sweden & Haiti \\
\hline Estonia & Switzerland & Lao PDR \\
\hline Finland & United Kingdom & Lesotho \\
\hline France & United States & Liberia \\
\hline Germany & Uruguay & Madagascar \\
\hline Greece & & Malawi \\
\hline Hungary & & Mali \\
\hline Ireland & & Mauritania \\
\hline Israel & & Mozambique \\
\hline Italy & & Myanmar \\
\hline Japan & & Nepal \\
\hline Korea, Rep. & & Niger \\
\hline Kuwait & & Rwanda \\
\hline Latvia & & Senegal \\
\hline Lithuania & & Sierra Leone \\
\hline Mauritius & & Sudan \\
\hline Netherlands & & Tanzania \\
\hline New Zealand & & Uganda \\
\hline Norway & & Zambia \\
\hline
\end{tabular}

